Prepared in cooperation with the National Park Service

\title{
Assessment of the Use of Sorbent Amendments for Reduction of Mercury Methylation in Wetland Sediment at Acadia National Park, Maine
}

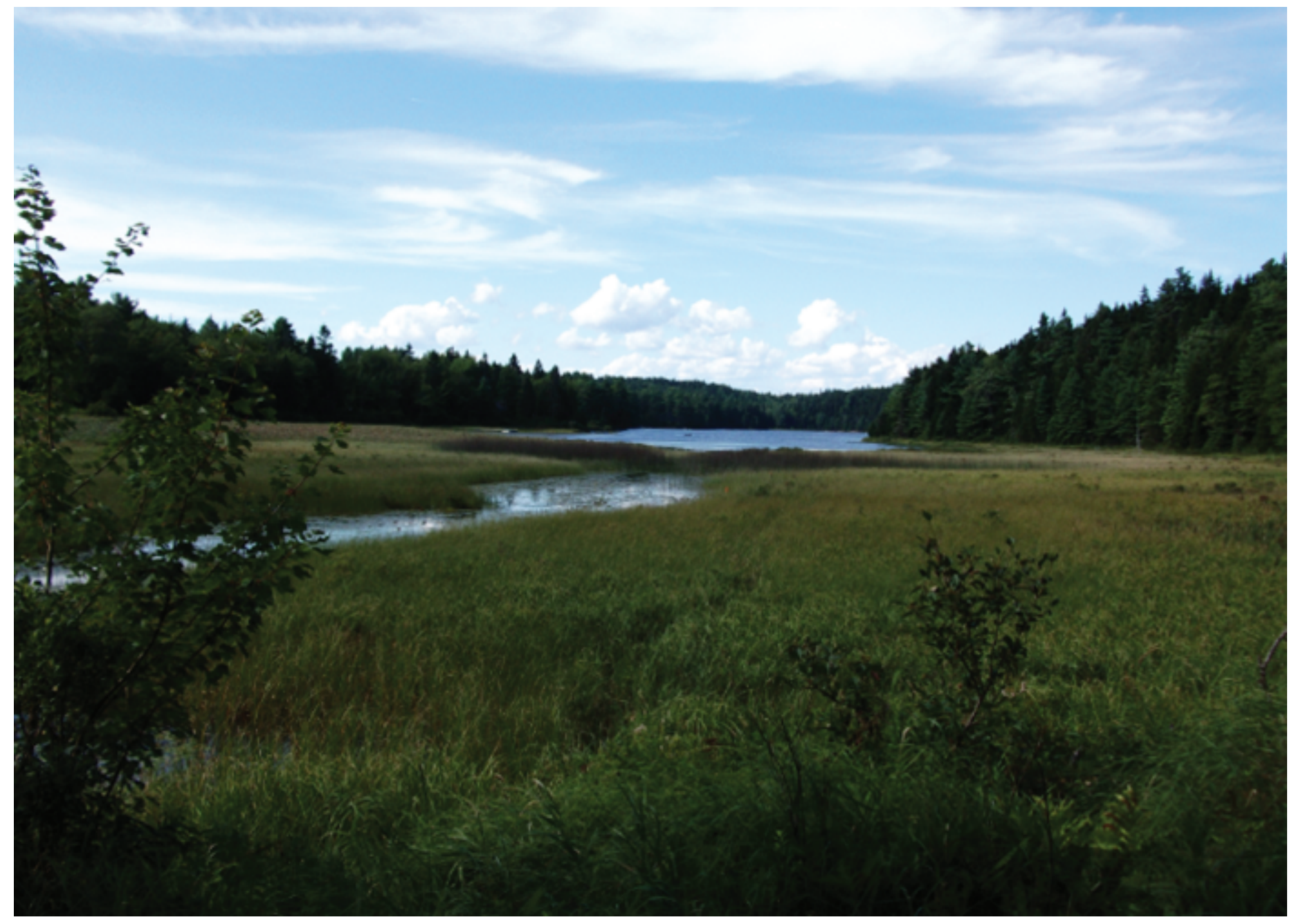

Scientific Investigations Report 2014-5234 
Front cover. Photograph of Hodgdon Pond at Acadia National Park, on August 12, 2013, from a point near the outlet of the pond looking north. Extensive wetlands occur on east and west sides of the outlet stream. Photograph courtesy of Ariel Lewis, University of Maine, Orono, Maine. 


\section{Assessment of the Use of Sorbent Amendments for Reduction of Mercury Methylation in Wetland Sediment at Acadia National Park, Maine}

By Thomas G. Huntington, Ariel Lewis, Aria Amirbahman, Mark Marvin-DiPasquale, and Charles W. Culbertson

Prepared in cooperation with the National Park Service

Scientific Investigations Report 2014-5234 


\title{
U.S. Department of the Interior SALLY JEWELL, Secretary
}

\section{U.S. Geological Survey Suzette M. Kimball, Acting Director}

\author{
U.S. Geological Survey, Reston, Virginia: 2015
}

For more information on the USGS - the Federal source for science about the Earth, its natural and living resources, natural hazards, and the environment, visit http://www.usgs.gov or call 1-888-ASK-USGS.

For an overview of USGS information products, including maps, imagery, and publications, visit http://www.usgs.gov/pubprod

To order this and other USGS information products, visit http://store.usgs.gov

Any use of trade, firm, or product names is for descriptive purposes only and does not imply endorsement by the U.S. Government.

Although this information product, for the most part, is in the public domain, it also may contain copyrighted materials as noted in the text. Permission to reproduce copyrighted items must be secured from the copyright owner.

Suggested citation:

Huntington, T.G., Lewis, Ariel, Amirbahman, Aria, Marvin-DiPasquale, Mark, and Culbertson, C.W., 2015, Assessment of the use of sorbent amendments for reduction of mercury methylation in wetland sediment at Acadia National Park, Maine: U.S. Geological Survey Scientific Investigations Report 2014-5234, 30 p., http://dx.doi.org/10.3133/ sir20145234.

ISSN 2328-0328 (online) 


\section{Acknowledgments}

The authors are grateful for the support they received from several people that contributed to the successful completion of this study. David Manski and Bill Gawley of Acadia National Park, National Park Service helped facilitate this report from the initial conceptualization of the study through completion. Clive Devoy at the University of Maine in Orono provided assistance with the chemical analysis of pore water and sediment at the Sawyer Environmental Laboratory.

Martha Nielsen of the U.S. Geological Survey provided the map used in figure 1. Marie-Noële Croteau of the U.S. Geological Survey provided adult snails for rearing juveniles and provided assistance with the methods used to rear and process snails for analysis in experiments involving metal uptake. Evangelos Kakouros, Michelle Arias, and Le Kieu of the U.S. Geological Survey processed and analyzed sediment iron and mercury species and snail tissue for mercury species. 



\section{Contents}

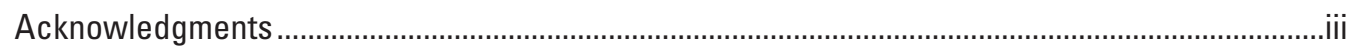

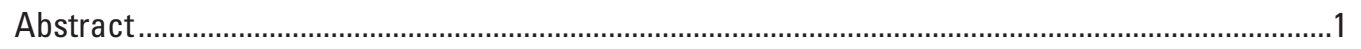

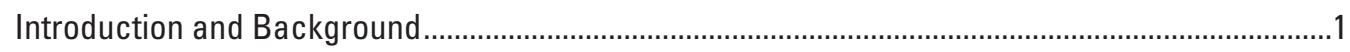

The Mercury Contamination Problem .................................................................................

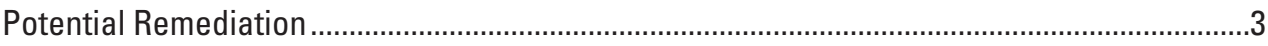

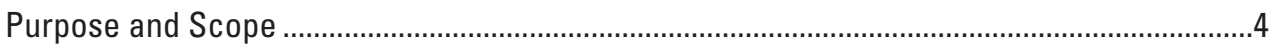

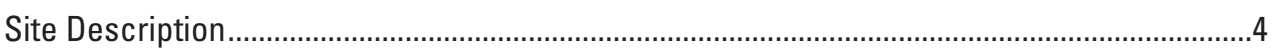

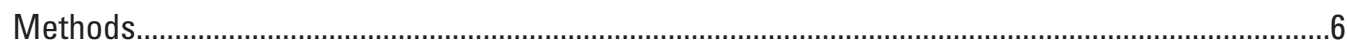

Experiment 1 (Littoral Zone Sediment) ..................................................................................

Experiment 2 (Profundal Zone Sediment) ...............................................................................

Experiment 3 (Vegetated Microcosms With Great Pond Snails With No Pore-Water

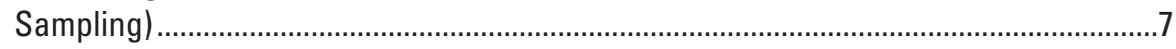

Experiment 4 (Field Mesocosms With Pore-Water Sampling) ................................................

Experiment 5 (Vegetated Microcosms With Snails) ..............................................................

Laboratory Analytical Procedures for Experiments 1 and 2 ..........................................................

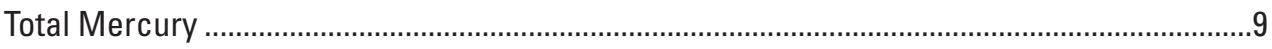

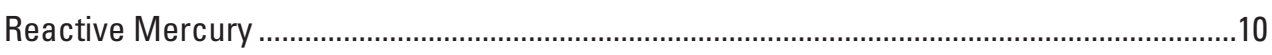

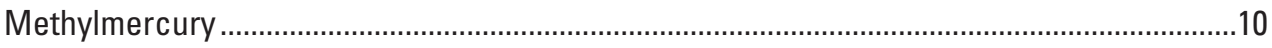

Sediment Bulk Density, Percent Dry Weight, Porosity, and Organic Content .........................10

Total Reduced Sulfur ..........................................................................................................

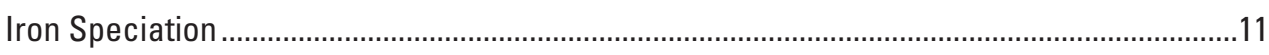

Laboratory Analytical Procedures for Pore Water Collected From Experiments 1, 2, 4, and 5

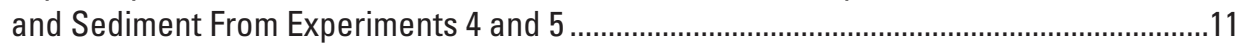

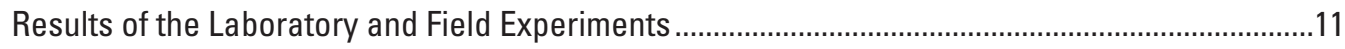

Chemical Characteristics of Littoral Sediment and Sediment Pore Water..............................11

Effects of Zero-Valent Iron on Pore-Water Chemistry From Littoral Sediment (Experiment 1) ................................................................................................12

Effects of Zero-Valent Iron on Pore-Water Chemistry From Profundal Sediment (Experiment 2) ..........................................................................................................12

Effects of Zero-Valent Iron on Sediment Chemistry and Uptake of Mercury in Snails Using Vegetated Littoral Sediment (Experiment 3) ...................................................12

Effects of Zero-Valent Iron and Granular Activated Carbon Treatments on Pore-Water and Sediment Chemistry in Field Mesocosms (Experiment 4).....................................17

Effects of Zero-Valent Iron and Granular Activated Carbon on Sediment Chemistry and Uptake of Mercury in Snails Using Vegetated Littoral Sediment (Experiment 5) .......19

Discussion of Experimental Results ......................................................................................19

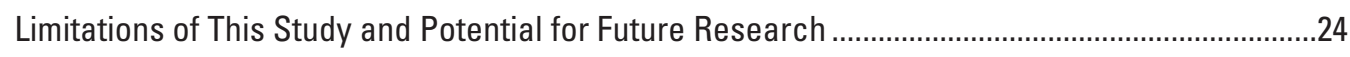

Summary

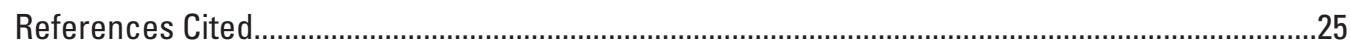




\section{Figures}

1. Map showing the watershed area draining to Hodgdon Pond, Mount Desert Island, Maine, and the location, dimensions, and hydrologic connectivity of wetlands within the catchment.

2. Graphs showing pore water concentration of $A$, ferrous iron for 5 and 50 times iron treatments, $B, \mathrm{pH}$ for 5 and 50 times iron treatments, $C$, ferrous iron collected from $2,4,6$, and 8 centimeters depth below the sediment-water interface, and $D, \mathrm{pH}$ collected from 2, 4, 6, and 8 centimeters depth below the sediment-water interface.

3. Plots showing the relation between concentrations of $A$, sediment methylmercury and amorphous trivalent iron and $B$, sediment $\mathrm{MeHg}$ and acid-extractable divalent iron, Experiment 3 for Mount Desert Island, Maine, for zero-valent iron treatment and untreated (reference) samples.

4. Graphs showing concentrations of methylmercury, sulfide, and divalent iron in pore water from field mesocosms following $A$, untreated (reference; Experiment 4), and treatments of $B$, zero-valent iron treatment and $C$, granular activated carbon, sampled at Mount Desert Island, Maine, September 6 and November 11, 2013, at four depths below the sediment-water interface

5. Graph showing concentrations of methylmercury in pore water collected from field mesocosms from Mount Desert Island, Maine, on September 6 and November 11, 2013, for Experiment 4

6. Graphs showing concentrations of total mercury, methylmercury, and MeHg:THg for sediment sampled from field mesocosms (Experiment 4) from Mount Desert Island, Maine.

7. Graphs showing log of the distribution coefficient for concentrations of methylmercury between sediment and pore water sampled from field mesocosms (Experiment 4) for $A, 25$ days posttreatment; and $B, 91$ days posttreatment from Mount Desert Island, Maine.

8. Graph showing a comparison of concentrations of methylmercury in sediment (four samples) and pore water (two samples) sampled 125 and 154 days posttreatment of zero-valent iron and granular activated carbon in laboratory mesocosms containing vegetated sediment to untreated (reference) samples, Experiment 5, for Mount Desert Island, Maine.

\section{Tables}

1. Chemical characteristics of littoral sediment and pore water extracted from sediment from wetlands fringing Hodgdon Pond, Mount Desert Island, Maine.

2. Pore-water chemistry from laboratory microcosms with blended littoral sediment (Experiment 1) from Mount Desert Island, Maine.

3. Pore-water chemistry from laboratory microcosms with profundal sediment (Experiment 2) from Mount Desert Island, Maine...

4. Summary of sediment and snail chemistry from Experiment 3 vegetated mesocosms from Mount Desert Island, Maine, with great pond snails.

5. Summary of sediment and great pond snail chemistry from Experiment 5 for Mount Desert Island, Maine 


\section{Conversion Factors}

SI to Inch/Pound

\begin{tabular}{|c|c|c|}
\hline Multiply & By & To obtain \\
\hline \multicolumn{3}{|c|}{ Length } \\
\hline millimeter $(\mathrm{mm})$ & 0.03937 & inch (in.) \\
\hline centimeter $(\mathrm{cm})$ & 0.3937 & inch (in.) \\
\hline meter $(\mathrm{m})$ & 3.281 & foot $(\mathrm{ft})$ \\
\hline kilometer $(\mathrm{km})$ & 0.6214 & mile (mi) \\
\hline meter $(\mathrm{m})$ & 1.094 & yard (yd) \\
\hline \multicolumn{3}{|c|}{ Area } \\
\hline square meter $\left(\mathrm{m}^{2}\right)$ & 0.0002471 & acre \\
\hline square meter $\left(\mathrm{m}^{2}\right)$ & 10.76 & square foot $\left(\mathrm{ft}^{2}\right)$ \\
\hline hectare (ha) & 2.471 & acre \\
\hline square centimeter $\left(\mathrm{cm}^{2}\right)$ & 0.1550 & square inch $\left(\mathrm{ft}^{2}\right)$ \\
\hline \multicolumn{3}{|c|}{ Volume } \\
\hline cubic centimeter $\left(\mathrm{cm}^{3}\right)$ & 0.06102 & cubic inch $\left(\right.$ in $\left.^{3}\right)$ \\
\hline liter (L) & 1.057 & quart (qt) \\
\hline \multicolumn{3}{|c|}{ Mass } \\
\hline $\operatorname{gram}(\mathrm{g})$ & 0.03527 & ounce, avoirdupois (oz) \\
\hline kilogram (kg) & 2.205 & pound avoirdupois (lb) \\
\hline
\end{tabular}

Temperature in degrees Celsius $\left({ }^{\circ} \mathrm{C}\right)$ may be converted to degrees Fahrenheit $\left({ }^{\circ} \mathrm{F}\right)$ as ${ }^{\circ} \mathrm{F}=\left(1.8 \times{ }^{\circ} \mathrm{C}\right)+32$.

\section{Datum}

Vertical coordinate information is referenced to the North American Vertical Datum of 1988 (NAVD 88).

Horizontal coordinate information is referenced to North American Datum of 1983 (NAD 83).

Altitude, as used in this report, refers to distance above the vertical datum.

\section{Supplemental Information}

Specific conductance is given in microsiemens per centimeter at 25 degrees Celsius $(\mu \mathrm{S} / \mathrm{cm}$ at $\left.25^{\circ} \mathrm{C}\right)$.

Concentrations of chemical constituents in water are given either in milligrams per liter (mg/L) or micrograms per liter $(\mu \mathrm{g} / \mathrm{L})$. 


\section{Acronyms, Abbreviations, and Chemical Elements}

\section{Acronyms}

$\begin{array}{ll}\text { \%LOI } & \text { percent loss on ignition } \\ \text { ANP } & \text { Acadia National Park } \\ \text { CVAFS } & \text { cold vapor atomic fluorescence spectroscopy } \\ \text { DMA } & \text { Direct Mercury Analyzer } \\ \text { DOC } & \text { dissolved organic carbon } \\ \text { DOM } & \text { dissolved organic matter } \\ \text { EPA } & \text { U.S. Environmental Protection Agency } \\ \text { GAC } & \text { granular activated carbon } \\ \text { HDPE } & \text { high density polyethylene } \\ \text { K } & \text { sediment-pore water distribution coefficient } \\ \text { LDPE } & \text { low density polyethylene } \\ \text { MOD } & \text { moderately hard water } \\ \text { PTFE } & \text { polytetrafluoroethylene, Teflon }{ }^{\circledR} \\ \text { PVC } & \text { polyvinyl chloride } \\ \text { RPD } & \text { relative percent deviation } \\ \text { THg } & \text { total mercury } \\ \text { TRS } & \text { total reduced sulfur } \\ \text { USGS } & \text { U.S. Geological Survey } \\ \text { ZVI } & \text { zero-valent iron }\end{array}$

\section{Abbreviations}

$\begin{array}{ll}\mathrm{mg} & \text { milligram } \\ \mathrm{mg} / \mathrm{kg} & \text { milligram per kilogram } \\ \mathrm{mL} & \text { milliliter } \\ \mathrm{ng} & \text { nanogram } \\ \mathrm{ng} / \mathrm{g} & \text { nanogram per gram (part per billion) } \\ \mathrm{ng} / \mathrm{g} / \mathrm{d} & \text { nanogram per gram (of dry sediment) per day; also } \mathrm{ng} / \mathrm{g} \mathrm{dry} \mathrm{sed} / \mathrm{d} \\ \mathrm{ng} / \mathrm{L} & \text { nanogram per liter } \\ \mu \mathrm{g} & \text { microgram } \\ \mu \mathrm{g} / \mathrm{g} & \text { microgram per gram }\end{array}$




$\begin{array}{ll}\mu \mathrm{g} / \mathrm{kg} & \text { microgram per kilogram } \\ \mu \mathrm{L} & \text { microliter } \\ \mu \mathrm{m} & \text { microns } \\ \mu \mathrm{mol} / \mathrm{L} & \text { micromoles per liter } \\ \mu \mathrm{S} / \mathrm{cm} & \text { microsiemens per centimeter }\end{array}$

\section{Chemical Elements and Compounds}

\begin{tabular}{|c|c|}
\hline $\mathrm{BrCl}$ & bromium chloride \\
\hline $\mathrm{CaSO}_{4} \cdot 2 \mathrm{H}_{2} \mathrm{O}$ & calcium sulfate dihydrate \\
\hline $\mathrm{Fe}$ & iron \\
\hline $\mathrm{Fe}(\mathrm{II})$ & divalent iron, ferrous iron, $\mathrm{Fe}^{2+}$ \\
\hline $\mathrm{Fe}(\mathrm{II})_{\mathrm{AE}}$ & acid-extractable ferrous iron \\
\hline $\mathrm{Fe}(I I I)$ & trivalent iron, $\mathrm{Fe}^{3+}$ \\
\hline $\mathrm{HCl}$ & hydrochloric acid \\
\hline $\mathrm{Hg}$ & mercury \\
\hline $\mathrm{Hg}(0)$ & elemental mercury \\
\hline $\mathrm{Hg}(\mathrm{II})$ & divalent mercury \\
\hline $\mathrm{Hg}(\mathrm{II})_{\mathrm{R}}$ & reactive mercury \\
\hline $\mathrm{HgS}$ & mercury sulfide \\
\hline $\mathrm{H}_{2} \mathrm{~S}$ & hydrogen sulfide \\
\hline $\mathrm{KCl}$ & potassium chloride \\
\hline $\mathrm{MeHg}$ & methylmercury \\
\hline $\mathrm{MgSO}_{4}$ & magnesium sulfate \\
\hline MOD & moderately hard water \\
\hline $\mathrm{NaHCO}_{3}$ & sodium bicarbonate \\
\hline $\mathrm{NaOH}$ & sodium hydroxide \\
\hline $\mathrm{NH}_{2} \mathrm{OH}-\mathrm{HCl}$ & hydroxylamine hydrochloride \\
\hline $\mathrm{ZnAc}$ & zinc acetate \\
\hline רS & zinc sulfide \\
\hline
\end{tabular}





\title{
Assessment of the Use of Sorbent Amendments for Reduction of Mercury Methylation in Wetland Sediment at Acadia National Park, Maine
}

\author{
By Thomas G. Huntington, ${ }^{1}$ Ariel Lewis, ${ }^{2}$ Aria Amirbahman, ${ }^{2}$ Mark Marvin-DiPasquale, ${ }^{1}$ and \\ Charles W. Culbertson'
}

\section{Abstract}

Mercury is a contaminant of ecological concern because of its ubiquity and toxicity to fish and wildlife, and is considered a severe and ongoing threat to biota at Acadia National Park in Maine. The formation and biomagnification of methylmercury is the primary concern of resource managers at Acadia, and information is needed to develop strategies for remediation or mitigation of this contaminant. The U.S. Geological Survey in cooperation with Acadia National Park, National Park Service carried out a series of laboratory and field experiments to evaluate the potential of zero-valent iron and granular activated carbon to reduce the rate of the bacterially mediated process of mercury methylation and subsequent biological uptake by the great pond snail Lymnaea stagnalis. The addition of zero-valent iron resulted in an increase in ferrous iron that was then further oxidized to poorly crystalline amorphous ferric iron, as was anticipated. Our original hypothesis was that these reactions would reduce methylation by decreasing the concentrations of substrates for bacterial methylation (sulfide and divalent mercury) through sorption to ferric iron surfaces, formation of iron sulfide compounds, or conversion of mercury to gaseous forms and subsequent evasion. The results of our experiments did not consistently support this hypothesis. In one experiment the application of zero-valent iron increased the amount of methylmercury associated with surficial sediment. In another experiment zero-valent iron decreased the amount of methylmercury associated with surficial sediment. The addition of zero-valent iron may have stimulated mercury methylation by iron reducing bacteria and if that effect outweighed the processes that could have decreased methylation then methylation would not be decreased.
The results of field mesocosm experiments indicated that there was a decreasing trend in pore-water methylmercury concentration after application of granular activated carbon but methylation was not affected because there was no corresponding decrease in sediment methylmercury concentration. The application of granular activated carbon resulted in the sorption of methylmercury. The application of granular activated carbon resulted in an increase in the distribution coefficient for methylmercury indicating that this amendment caused a higher proportion of methylmercury to be associated with the sediment than the pore water in comparison to the reference (untreated) condition. Experiments to test whether zero-valent iron or granular activated carbon would reduce the biouptake of methylmercury in snails were inconsistent; zero-valent iron had no effect on uptake in one experiment but resulted in a significant decrease in uptake in a second experiment. Granular activated carbon did not affect biouptake in either experiment.

\section{Introduction and Background}

The introduction and background is divided into four sections. The first section describes the problem of mercury (Hg) contamination, the concept of biomagnification, previous studies documenting mercury contamination in biota at Acadia National Park. The first section also describes the process of microbial methylation of mercury and the purpose of this report. The second section describes mechanisms of potential remediation of mercury contamination using chemical amendments. The third section is a brief statement of the purpose and scope of the report. The final section is a brief site description. The purpose of this report is to provide Acadia National Park resource managers with information that could be used to develop strategies to reduce the methylation and biological uptake of methylmercury ( $\mathrm{MeHg})$.

${ }^{1}$ U.S. Geological Survey.

${ }^{2}$ University of Maine. 


\section{The Mercury Contamination Problem}

Mercury is a widespread contaminant of ecological concern because of its ubiquity and toxicity to fish and wildlife in environmental settings where it accumulates in biota and is biomagnified. The adverse effects of mercury exposure are commonly associated with its neurotoxicity; however, mercury exposure also has been linked to immune suppression, endocrine disruption, physical malformations, and mortality in organisms (Eisler, 2006; Scheuhammer and others, 2007; Tan and others, 2009; Wada and others, 2009; Weiner and Spry, 1996; Wolfe and others, 1998). The threat of this toxin to human health has resulted in the establishment of consumption advisories for marine and freshwater fish in 44 States in the United States, including much of the east coast (including Maine) and all eastern Canadian Provinces.

Based on indirect evidence, such as mercury found in lake sediment, atmospheric deposition of mercury from nonpoint sources increased in the continental United States from the late 1800 s to the 1990 s by 2.5 to 15 fold (Driscoll and others, 2007) resulting in an increase in the extent of mercury contamination in fish in freshwater and coastal environments (Boesch and others, 2001). Since the 1990s measurements indicate decreases in wet deposition (from precipitation samples) of mercury over the continental United States averaging -4.1 plus or minus 0.49 percent per year for the period from 2004 to 2010 (Zhang and Jaeglé, 2013).

Biomagnification is the process by which the concentration of a contaminant increases from the environment at large through successively higher trophic levels within the food chain because of the contaminant being very slowly metabolized or excreted. Biomagnification of $\mathrm{Hg}$ is a severe and ongoing threat to biota at Acadia National Park (ANP; Acadia National Park, 2010), as elevated concentrations have been documented in amphibian, reptiles, birds, fish, and mammals (Bank and others, 2005, 2007a, b; Longcore and others, 2007). Average mercury concentrations in fish fillets from predator fish from 11 lakes at Acadia National Park exceeded health thresholds established for the safe consumption of fish by humans and wildlife (Acadia National Park, 2010). Biomagnification of mercury in the great pond snail Lymnaea stagnalis has been studied in microcosm experiments (Tessier and others, 2007).

In one study at Acadia National Park bullfrog and green frog tadpoles collected from nine ponds had median total mercury $(\mathrm{THg})$ concentrations of 0.075 milligrams per kilogram $(\mathrm{mg} / \mathrm{kg})$ wet weight and the median percent $\mathrm{MeHg}$ was 22 percent (Bank and others, 2007b). Among these ponds, the dimictic and mesotrophic Hodgdon Pond has an average sediment mercury concen-tration of $0.22 \mathrm{mg} / \mathrm{kg}$, and one of the highest water and fish mercury concentrations among Maine lakes. In summer 2010, Hodgdon Pond had average surface water $\mathrm{THg}$ and $\mathrm{MeHg}$ concentrations of 2.63 nanograms per liter $(\mathrm{ng} / \mathrm{L})$ and $1.8 \mathrm{ng} / \mathrm{L}$, respectively, and an average mercury body burden in the predatory smallmouth bass Micropterus dolomieu greater than (>)
$2 \mathrm{mg} / \mathrm{kg}$ wet weight (Linda Bacon and Aria Amirbahman, unpub. data, [February 15, 2014]), well in excess of the U.S. Environmental Protection Agency (EPA) $0.3 \mathrm{mg} / \mathrm{kg}$ fish consumption advisory for $\mathrm{MeHg}$ (U.S. Environmental Protection Agency, 2001). Mercury accumulation rates in bog and pond sediment at two locations at Acadia National Park during the 1980s were reported to be in the range of 100 to 200 micrograms per square meter per year ( $\mu \mathrm{g} / \mathrm{square}$ meter/ year) (Norton and others, 1997). Amirbahman and others (2004) reported THg and $\mathrm{MeHg}$ concentrations of 180 grams per hectare $(\mathrm{g} / \mathrm{ha})$ and $0.16 \mathrm{~g} / \mathrm{ha}$, respectively, in undisturbed Acadia National Park forest soil. At Acadia National Park, wetland soil has significantly higher $\mathrm{MeHg}$ concentrations (about 3.0 micrograms per kilogram $(\mu \mathrm{g} / \mathrm{kg})$ dry weight) compared with the well-drained upland soil (about $0.2 \mu \mathrm{g} / \mathrm{kg}$ dry weight; Ruck, 2002).

The principal nonpoint source of $\mathrm{Hg}$ in the natural environment is atmospheric deposition, a major part of which originates from waste incineration and the combustion of fossil fuels. The annual rate of atmospheric wet deposition of THg in the northeastern United States is 6 to 8 micrograms per meter square meter ( $\mu \mathrm{g} / \mathrm{square}$ meter) (Prestbo and Gay, 2009). Divalent mercury ( $\mathrm{Hg}[\mathrm{II}])$ is the dominant form of mercury in atmospheric deposition. Once deposited in terrestrial or aquatic environments mercury can enter into complex biogeochemical processes (abiotic and biotic) in which it can be converted into other forms of mercury. From the standpoint of environmental contamination and biological toxicity, it is the formation of $\mathrm{MeHg}$ that is of most concern because this form bioaccumulates to as much as a factor of $10^{7}$ in the food chain to concentrations that are harmful or lethal (for example, Driscoll and others, 2007). It has been proposed that methylation is brought about by bacteria that have taken up small, uncharged mercury complexes (for example, neutral aqueous mercury sulfide $\left(\mathrm{HgS}^{0}[\mathrm{aq}]\right)$ and mercury disulfide $\left(\mathrm{HgHS}_{2}{ }^{0}\right)$ capable of passive diffusion across bacterial cell membranes (Benoit and others, 1999, 2001). The produced MeHg may be taken up by phytoplankton or other organisms, which are then consumed by zooplankton. The factors controlling the rates of $\mathrm{Hg}$ (II) methylation and $\mathrm{MeHg}$ demethylation (Oremland and others, 1991) determine environments likely to lead to toxicity in biota.

Microbial methylation of $\mathrm{Hg}(\mathrm{II})$ to $\mathrm{MeHg}$ is affected by environmental factors, including temperature, dissolved oxygen concentrations/redox status, dissolved organic carbon (DOC) concentration and composition, sulfate, $\mathrm{pH}$, and the activity of the sulfate reducing bacteria (Compeau and Bartha, 1985; Gilmour and others, 1992; Benoit and others, 2003; Marvin-DiPasquale and others, 2009a,b) and trivalent iron (Fe[III]) reducing bacteria (Warner and others, 2003; Schafer and Morel, 2009). In the northeastern United States, there is a positive relation between concentrations of total organic carbon and total elemental mercury $(\mathrm{Hg}(0))$ and $\mathrm{MeHg}$ in surface water (Dennis and others, 2005). Organic carbon in surface water that is in equilibrium with sediment pore water may enhance methylation in sediment. Macrophytes also may 
affect methylation in wetlands through effects on $\mathrm{pH}$, redox potential $\left(\mathrm{E}_{\mathrm{h}}\right)$ and by the exudation of organic ligands (Cosio and others, 2014).

Mercury methylation is reported to exist largely in the surficial sediment zone (Han and others, 2007; Sunderland and others, 2004). Mercury accumulation rates in ponds, however, are higher than in their surrounding watersheds because of accumulation of mercury from surrounding watershed runoff (Perry and others, 2005). Dissolved organic carbon can form complexes with $\mathrm{Hg}(\mathrm{II})$ and sulfide, thus facilitating transport of these precursors for methylation from terrestrial to aquatic environments.

\section{Potential Remediation}

Potential remediation of mercury contamination in ponds with the ultimate goal of decreasing MeHg uptake in higher trophic level biota could be accomplished through different mechanisms. One approach is to apply a chemical amendment that has the potential to reduce the concentration of $\mathrm{Hg}$ (II) available for $\mathrm{Hg}$ (II)-methylation by reduction to volatile elemental $\mathrm{Hg}(0)$ (Vernon and Bonzongo, 2014). Another approach is to add a complexation agent that has the potential to reduce the concentration of sulfides that are reported to facilitate $\mathrm{Hg}(\mathrm{II})$-methylation by the formation of neutral mercury sulfide (HgS) complexes (Mehrotra and Sedlak, 2005). One of the more common approaches to remediation is to add a sorbent to adsorb $\mathrm{Hg}$ (II) and $\mathrm{MeHg}$, thus decreasing the concentrations of the $\mathrm{MeHg}$ precursor and product (Weisener and others, 2005; Vernon and Bonzongo, 2014. Zero-valent iron (ZVI) has the potential to reduce $\mathrm{Hg}(\mathrm{II})$-methylation through all of these mechanisms. Some amendments like biochar or granular activated carbon (GAC) can act as sorbents for $\mathrm{Hg}$ (II) and $\mathrm{MeHg}$ and may serve as reactive barriers to the movement of mercury in soil and sediment (Gilmour and others, 2013).

According to the model proposed by Benoit and coworkers (Benoit and others, 1999, 2001), one of the factors limiting $\mathrm{Hg}$ (II)-methylation is the concentration of the dissolved neutral $\mathrm{HgS}$ complexes, because only these complexes are capable of passive diffusion across bacterial cell membranes. The concentration of these complexes, in turn, is dependent on the concentration of dissolved $\mathrm{Hg}(\mathrm{II})$ and the concentration of dissolved sulfide. Anything that lowers the concentrations of either constituent or actively competes with either constituent to form other complexes or compounds that are not capable of diffusion across microbial membranes will slow the rate of $\mathrm{Hg}(\mathrm{II})$-methylation (Benoit and others, 1999, 2001). Historical and ongoing mercury contamination from atmospheric deposition, as well as in place biogeochemical processes, result in a steady supply of mercury species that are available for $\mathrm{Hg}(\mathrm{II})$-methylation (Ulrich and others, 2001). Natural and anthropogenic sources (acidic deposition) of sulfate provide a steady supply of sulfate for bacterial conversion to sulfide ([sulfate reducers that methylate $\mathrm{Hg}$ ] in anaerobic sediment Gilmour and Henry, 1991). In ponds that stratify during the summer, like Hodgdon Pond at Acadia National Park, surface sediment likely is suboxic or anoxic throughout the summer season, thus favoring anaerobic microbial processes, such as iron and sulfate reduction (Benoit and others, 2003; Kerin and others, 2006; Schafer and Morel, 2009). Therefore, to reduce $\mathrm{Hg}(\mathrm{II})$-methylation one of the more promising remediation options would be to reduce the availability of $\mathrm{Hg}$ (II) otherwise available for $\mathrm{Hg}(\mathrm{II})$-methylation and inhibit the formation of the neutral $\mathrm{Hg}-\mathrm{S}$ complexes.

The addition of $\mathrm{Fe}(\mathrm{II})$ has been reported to inhibit $\mathrm{Hg}$ (II)-methylation in controlled laboratory studies with sediment slurries and mesocosms (Mehrotra and others, 2003; Mehrotra and Sedlak, 2005, Liu and others, 2009). There are at least three mechanisms by which iron addition could reduce the net rate of $\mathrm{Hg}$ (II)-methylation. In the first mechanism, $\mathrm{Fe}(\mathrm{II})$ reduces the dissolved sulfide concentration through the formation of solid iron sulfide (FeS[s]) (Mehrota and others, 2003) to the extent that the formation of neutral $\mathrm{HgS}$ is inhibited (Ulrich and Sedlak, 2010), or charged $\mathrm{Hg}$ (II)-polysulfides are formed (Liu and others, 2009). A second mechanism is that the addition of iron results in the formation of amorphous iron hydroxide $\left(\mathrm{FeOH}_{3(\mathrm{~s})}\right)$, the surface of which is highly reactive and has a high affinity for $\mathrm{Hg}$ (II) (Tiffreau and others, 1995), thus decreasing the concentration of dissolved $\mathrm{Hg}$ (II) available for $\mathrm{Hg}(\mathrm{II})$-methylation. A third mechanism holds that iron additions may cause $\mathrm{Hg}$ (II) to be reduced to elemental $\mathrm{Hg}(0)$ (Charlet and others, 2002; Peretyazhko and others, 2006; Amirbahman and others, 2013), decreasing the amount of $\mathrm{Hg}$ (II) available for methylation.

The addition of ZVI to suboxic aquatic sediment will cause a series of reactions that include production of hydrogen $\left(\mathrm{H}_{2}\right)$ from water and co-reactions on iron surfaces whereby $\mathrm{Fe}^{0}$ is oxidized to ferrous, $\mathrm{Fe}$ (II), and ferric trivalent iron $\mathrm{Fe}$ (III). These reactions will elevate $\mathrm{Fe}$ (II) and $\mathrm{Fe}(\mathrm{III})$ concentrations that, in theory, will constitute a protective reactive barrier (an iron curtain), by the mechanisms mentioned above, to reduce the concentration of $\mathrm{Hg}$ (II) species available for methylation (that is neutral $\mathrm{Hg}-\mathrm{S}$ complexes). ZVI has been reported to have potential as a protective reactive barrier for mercury in field column studies and is capable of accumulating mercury as a $\mathrm{Hg}$-sulfide complex with a stoichiometry similar to the mercury sulfide minerals cinnabar and metacinnabar in contaminated groundwater (Weisener and others, 2005). The fate of the added ZVI may depend on the unique sediment redox conditions; in oxic environments, the presence of ZVI leads to the formation of $\mathrm{Fe}(\mathrm{III})$ species and $\mathrm{FeOH}_{3(\mathrm{~s})}$, whereas in anoxic environments, the presence of ZVI leads preferentially to the formation of $\mathrm{Fe}$ (II) species, including Fe-sulfide complexes, and $\mathrm{FeS}_{(\mathrm{s})}$. ZVI should persist in surficial sediment, as the iron corrodes and fresh reactive surfaces continually form. Some of the conversion of ZVI to Fe(II) may be microbially mediated (Roden and Wetzel, 2002).

It was once considered that in suboxic wetland sediment that sulfate reducing bacteria were exclusively responsible for $\mathrm{Hg}(\mathrm{II})$-methylation but it is now recognized that other bacteria including Fe-reducers and methanogens also are capable of methylating mercury (Kerin and others, 2006; 
Fleming and others, 2006, Hamelin and others, 2011). It also was reported that transport across the cell membrane was passive but it has recently been reported that it can be an active process (Schaefer and others, 2011). Which group of bacteria is responsible for $\mathrm{Hg}(\mathrm{II})$-methylation in any given environment is probably dependent on several factors and is not easy to predict. Bacteria also demethylate mercury and it is the net rate of $\mathrm{MeHg}$ production that will determine the potential for biological uptake (Marvin-DiPasquale and others, 2000). Because methylation and demethylation are complex interacting processes dependent on many environmental variables it is difficult to predict the effect of a given amendment therefore experimentation is necessary.

The application of sorbent amendments in the field is emerging as a potential approach for the remediation or management of mercury-contaminated sediment (Ghosh and others, 2011). Sorbents bind contaminants and thereby reduce bioavailability. Sorbents can be applied as a cap where they can act as both sorbent and as a reactive barrier to the transport of the contaminant or they can be incorporated into contaminated sediment to maximize contaminant binding. There are potential pitfalls with both strategies, such as adverse effects on benthic fauna and flora. Mercury often is complexed with dissolved organic matter (Hg-DOM) in natural systems and DOM has been determined to have a strong affinity for activated carbon surfaces (Schreiber and others, 2005; Gerbig and others, 2011). Activated carbonaceous sorbents have been determined to reduce porewater contaminant concentrations (Gomez-Eyles and others, 2013) and reduce biouptake of mercury and MeHg (Ghosh and others, 2008, Gilmour and others, 2013).

There have been a few studies evaluating the potential for surface application of GAC to reduce pore-water mercury and $\mathrm{MeHg}$ and biouptake of these species (Ghosh and others, 2008, Gilmour and others, 2013), but no studies that we know of that have evaluated the potential for ZVI to reduce biouptake of MeHg. GAC studies usually have involved laboratory microcosms and not field studies, typically using homogenized and unvegetated sediment or sediment slurries. In place studies are much less common. This study was carried out as a preliminary evaluation of the potential for GAC and ZVI to reduce pore-water mercury and $\mathrm{MeHg}$ concentrations in place in freshwater wetland sediment. An additional purpose for this study was to evaluate the potential for GAC and ZVI to reduce mercury and $\mathrm{MeHg}$ concentrations in pore water and surficial bulk sediment in microcosms containing intact vegetated sediment in the laboratory. Finally, this study evaluated the potential for GAC and ZVI to reduce mercury and $\mathrm{MeHg}$ biouptake in the great pond snail L. stagnalis in microcosms containing intact vegetated sediment in the laboratory.

Surface applications of ZVI or GAC may be cost effective for treating surface sediment that are contaminated with atmospherically deposited mercury compared with treating large volumes of heavily contaminated soil or sediment. ZVI can be purchased for about $\$ 1,100$ per metric ton (Amy Marchefka, ConnellyGPM, Inc., written commun., July 28, 2014) and GAC could be purchased for about $\$ 2,100$ per metric ton (Ghosh and others, 2011). To treat 1 hectare (ha) with ZVI at the rate used in the field experiment in this study would require $864 \mathrm{~kg}$. To treat 1 ha with GAC at the rate used in the field experiment in this study would require $802 \mathrm{~kg}$. Actual costs would include costs associated with shipping and application.

\section{Purpose and Scope}

The purpose of this report is to provide Acadia National Park resource managers with information that could be used to develop strategies to reduce the methylation and biological uptake of MeHg. This report describes a series of laboratory and field experiments using wetland sediment from areas fringing Hodgdon Pond on Mount Desert Island to test if amendments including ZVI and GAC had the potential to reduce the methylation of mercury and biological uptake of $\mathrm{MeHg}$. This report includes descriptions of the effects of ZVI and GAC additions on pore-water chemistry at various depths below the sediment water interface, sediment chemistry, and mercury uptake in the great pond snail L. stagnalis.

\section{Site Description}

Hodgdon Pond in Tremont Township (not shown) on Mount Desert Island, Maine, was the subject of this study. The pond has a surface area of 18.2 ha and a perimeter of 3,300 meters (fig. 1) and fringing wetlands near the outlet at the southern end, on the western shore near the midpoint, and, at the northern end. Most of the Hodgdon Pond watershed lies within Acadia National Park, but the western shore is privately owned. Several wetlands have been identified within the Hodgdon Pond watershed that include wetlands that fringe the pond perimeter (lacustrine wetlands) as well as riverine, depressional, and slope wetlands in the larger pond catchment ( Nielsen, 2006, fig. 1). The nonlacustrine wetlands are located in first-, second-, or third-order catchments nested within the larger pond catchments and are hydrologically connected through ephemeral and perennial channels that drain into the pond (Nielsen, 2006, plate 1). These wetlands are likely important to the levels of MeHg observed in Hodgdon Pond because wetlands are estimated to contribute as much as 80 times more $\mathrm{MeHg}$ to receiving water bodies than upland areas (St. Louis and others, 1994).

Hodgdon Pond is 6.7 meters $(\mathrm{m})$ deep at the deepest point and has an average depth $3.35 \mathrm{~m}$ (Maine.gov, [2001]). The pond drains from north to south into the substantially larger Seal Cove Pond. The water level is variable depending on the season and antecedent precipitation conditions. Water quality data indicate a $\mathrm{pH}$ in the range of 6.2 to 6.5 and conductivity of 41 to 53 microsiemens per centimeter $(\mu \mathrm{S} / \mathrm{cm})$ at $25^{\circ} \mathrm{C}$ (Bacon, 2013). 


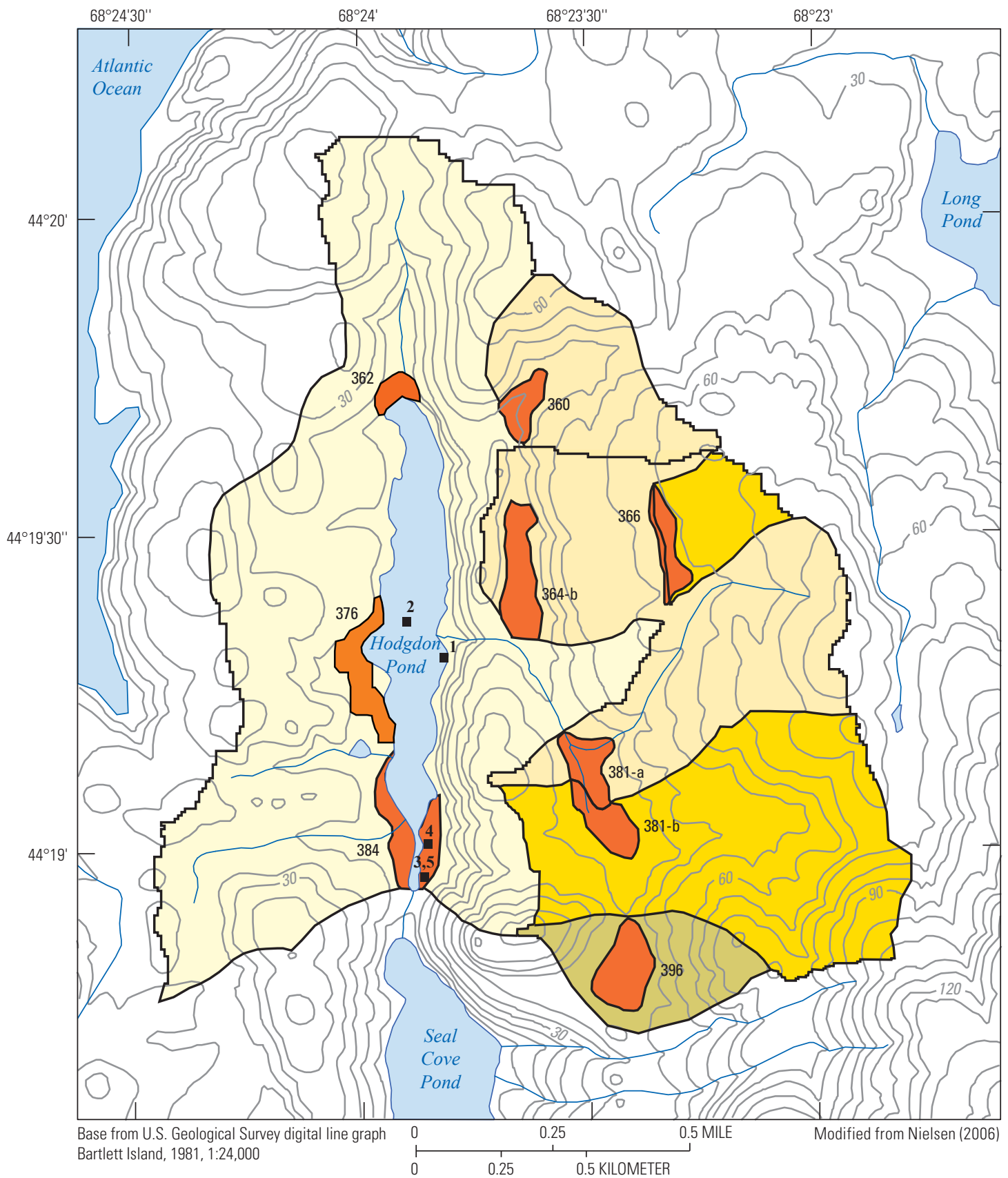

EXPLANATION

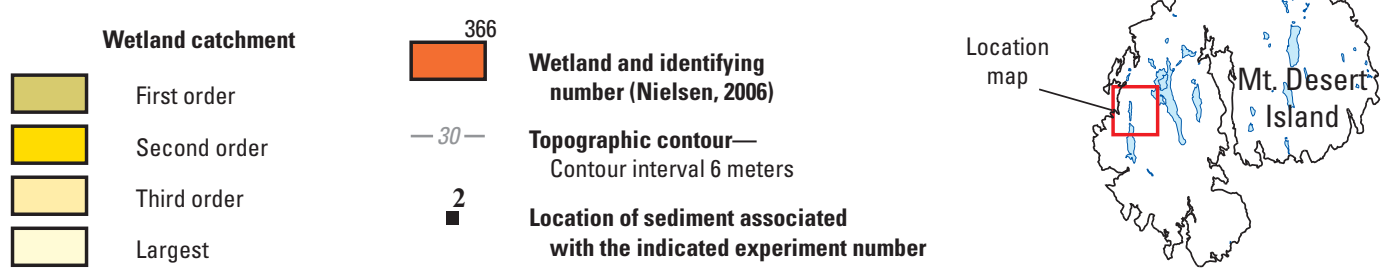

Figure 1. The watershed area draining to Hodgdon Pond, Mount Desert Island, Maine, and the location, dimensions, and hydrologic connectivity of wetlands within the catchment. The locations where the sediment was collected or instrumented is also shown with numbers corresponding to the experiments. This figure was modified from Nielsen (2006). The wetland identifier numbers are described in Nielsen (2006, table 2-1). 


\section{Methods}

Five experiments were carried out for this project. In the first experiment, sediment from the littoral zone of wetlands fringing Hodgdon Pond were maintained in cylindrical microcosms and treated with two levels of ZVI addition. In the second experiment, sediment from the profundal zone of Hodgdon Pond were maintained in cylindrical microcosms and treated with one level of ZVI addition. In the third experiment, vegetated intact sediment clumps from the littoral zone of wetlands fringing Hodgdon Pond were maintained in cylindrical microcosms and treated with one level of ZVI addition. Great pond snails (L. stagnalis) were used in this experiment to evaluate biouptake of $\mathrm{Hg}$. Great pond snails were selected as test organisms because they are relatively easy to raise and have been used successfully in short-term exposure metal uptake studies (Tessier and others, 2007, Croteau and others, 2009, 2011, Sychra and others, 2011). The microbial communities in periphyton (biofilms) can accumulate and methylate Hg (Desrosiers and others, 2006; Hamelin and others, 2011). Great pond snails consume periphyton (Farag and others, 1998) so that these snails are useful for studying bioaccumulation of $\mathrm{Hg}$ and $\mathrm{MeHg}$ in animals. In the fourth experiment, mesocosms were established in the littoral zone of wetlands fringing Hodgdon Pond and maintained from August through November 2013. In this experiment, one treatment involved the application of ZVI and another treatment involved the application of GAC. In the fifth experiment, vegetated intact sediment clumps from the littoral zone of wetlands fringing Hodgdon Pond were maintained in cylindrical microcosms and treated with one level of ZVI addition and one level of GAC addition. Great pond snails (L. stagnalis) were used in this experiment to evaluate biouptake of $\mathrm{Hg}$.

\section{Experiment 1 (Littoral Zone Sediment)}

Sediment was collected from fringing wetlands in the littoral zone midpoint eastern edge of Hodgdon Pond on November 18, 2011 (latitude 44 ${ }^{\circ} 19^{\prime} 18.9^{\prime \prime}$, longitude $\left.-68^{\circ} 23^{\prime} 46.8^{\prime \prime}\right)$. Intact columns 20 -cm deep and 10 -cm diameter were collected in clear plastic cylinders and were brought to the laboratory. Core material appeared to be extremely heterogeneous containing many coarse ( 1 to $1.5 \mathrm{~cm}$ diameter) roots and large voids (some filled with air and some with water). Because of the heterogeneity we concluded that Rhizon samplers (Rhizosphere Research Products) would be ineffective. All sediment was aggregated and the large roots were removed and then the sediment was blended to create a uniform and well-mixed material and was stored refrigerated at 3 degrees Celsius $\left({ }^{\circ} \mathrm{C}\right)$. The blended sediment was then repacked in the original $10-\mathrm{cm}$ diameter columns on February 2, 2012.

A subsample of the blended sediment was maintained refrigerated at $3{ }^{\circ} \mathrm{C}$ until March 21, 2012, when it was shipped on ice to the U.S. Geological Survey laboratory in Menlo
Park, California, for geochemical analysis. Upon arrival, the sample was subsampled in an anoxic glove bag for the following suite of whole sediment constituents: $\mathrm{THg}, \mathrm{MeHg}$, reactive mercury $\left(\mathrm{Hg}(\mathrm{II})_{\mathrm{R}}\right)$, percent dry weight, organic content (as percent loss on ignition [percent LOI]), grain size, total reduced sulfur (TRS) and iron speciation. The subsamples for $\mathrm{THg}$, $\mathrm{MeHg}, \mathrm{Hg}(\mathrm{II})_{\mathrm{R}}$, TRS and iron-speciation were all subsequently preserved frozen. The subsamples for dry weight, percent LOI and grain size were all subsequently preserved refrigerated. In addition, approximately 100 cubic centimeters $\left(\mathrm{cm}^{3}\right)$ of sediment was centrifuged and the supernatant subsequently filtered (0.45 microns $[\mu \mathrm{m}])$ in an anoxic glove bag for pore-water $\mathrm{THg}$ and $\mathrm{MeHg}$. Both of these fractions were then preserved with 0.5 percent trace metal clean hydrochloric acid $(\mathrm{HCl})$. Total iron as used in this report refers to the sum of the three fractions that were determined by speciation, acid-extractable divalent ferrous iron $\left(\mathrm{Fe}(\mathrm{II})_{\mathrm{AE}}\right)$, amorphous trivalent ferric iron (Fe(III)a), and crystalline trivalent ferric (Fe(III)c).

Columns were instrumented with Rhizon pore-water samplers inserted through ports machined into the sidewalls of the $10-\mathrm{cm}$ diameter cylinders. The Rhizons were connected to plastic tubing leading to a luer-lock syringe port. The pore size of the porous part of the Rhizons is 0.12 to $0.18 \mu \mathrm{m}$, hence filtering the samples before analyzing was unnecessary. The sediment was covered with approximately $3 \mathrm{~cm}$ of Hodgdon Pond water that was maintained at this depth with additions of Hodgdon Pond water as needed. The overlying water was aerated with aquarium pumps. Two columns were left untreated as reference treatments, two columns received $0.384 \mathrm{~g}$ of ZVI ( 5 times native iron) and two columns received $3.84 \mathrm{~g} \mathrm{ZVI}$ (50 times native iron). The ZVI was incorporated into the top 3 plus or minus $( \pm) 1 \mathrm{~cm}$ of sediment using a glass stirring rod to gently mix the sediment. Rhizon samplers were installed through ports in column walls at depths of approximately 2 , 4,6 , and $8 \mathrm{~cm}$ below the sediment water interface for collection of pore water. Pore water was sampled 12, 42, 53, 75, and 95 days following the addition of the treatments using syringes to apply suction to the Rhizon samplers.

Rhizon-collected pore-water samples were collected in two separate syringe pulls. The first pull of approximately 3 milliliters ( $\mathrm{mL}$ ) was allocated to ancillary chemistry: Fe(II), TOC, dissolved hydrogen sulfide, and $\mathrm{pH}$; 4-mL plastic bottles were prepared for preservation of each sample. For Fe(II), low density polyethylene (LDPE) bottles containing 100 microliters $(\mu \mathrm{L})$ of 1 Molar nitric acid $\left(1 \mathrm{M} \mathrm{HNO}_{3}\right)$ samples were frozen immediately after collection; for TOC, high density polyethylene (HDPE) vials were used and frozen immediately after taking a $\mathrm{pH}$ measurement; for dissolved hydrogen sulfide, low density polyethylene (LDPE) vials that contained $100 \mu \mathrm{L}$ of $1 \mathrm{M}$ zinc acetate (ZnAc) in 2 Molar sodium hydroxide $(2 \mathrm{M} \mathrm{NaOH})$ were frozen immediately after collection. The second pore-water sample was collected for THg measurement. Samples were collected in pre-weighed $15 \mathrm{~mL}$ polypropylene falcon tubes and preserved with 10-percent bromine chloride $(\mathrm{BrCl})$. Samples were refrigerated until analysis. 


\section{Experiment 2 (Profundal Zone Sediment)}

Sediment was collected from the profundal zone of Hodgdon Pond on May 30, 2012, in about $6 \mathrm{~m}$ of water (latitude $44^{\circ} 19^{\prime} 24.35^{\prime \prime}$, longitude $\left.-68^{\circ} 23^{\prime} 50.91^{\prime \prime}\right)$. A box-corer was used to collect the surface sediment (nominally from the top $5 \mathrm{~cm}$ ) from 10 locations within an area of about 60 meters squared $\left(\mathrm{m}^{2}\right)$ and the individual samples were composited and well mixed to obtain a representative sample. The sediment was packed in six $15-\mathrm{cm}$ diameter cylinders (microcosms) to a total depth of $16 \mathrm{~cm}$. These microcosms were constructed using plastic water jugs.

After a 31-day equilibration period two columns were left untreated as reference treatments, two columns received $0.878 \mathrm{~g}$ of ZVI (5 times native iron), and two columns received $8.73 \mathrm{~g} Z \mathrm{ZVI}$ (50 times native iron). The ZVI was incorporated into the top $3 \mathrm{~cm}$ of sediment. All columns had $2 \mathrm{~cm}$ sediment above the topmost port that was set in the middle of the layer that the ZVI. Aquarium pumps were used to keep the overlying water aerated from July 2 through 12 , 2012, and after this initial period the aeration was removed.

Each microcosm was fitted with an equilibrium dialysis frame with draw ports in the back (known as a draw-peeper) for pore-water sampling. Every other cell (beginning with the bottom-most cell) of the draw-peeper was modified by drilling a hole, threading it, and installing a connector to adapt this opening to a $1 / 16$-inch polytetrafluoroethylene, Teflon ${ }^{\circledR}$ (PTFE) tube that reached the surface, and connected to a luer-lock on the for pulling in-place samples. The holes were staggered to prevent stress on the draw-peeper's frame. This resulted in a total of four draw-cells per draw-peeper.

Draw-peepers were acid-leached (10-percent $\mathrm{HCl})$ then rinsed by soaking for 2 weeks in a deionized water (D.I. $\mathrm{H}_{2} \mathrm{O}$ ) bath in which the water was changed every 3 days. Frames were assembled by submerging the base plate in D.I. $\mathrm{H}_{2} \mathrm{O}$, placing a precut polysulfone dialysis membrane $(0.45 \mu \mathrm{m})$ across the filled cells and then securing the face plate with nylon screws. The frames were immersed in portable tank columns and bubbled with nitrogen $\mathrm{N}_{2}$ for 2 weeks before deployment (Carignan and others, 1994). Immediately following deoxygenation draw-peepers were inserted into the sediment of each of the microcosms on May 30, 2012, so that the uppermost draw-cell was centered about $2 \mathrm{~cm}$ below the sediment water interface. The other draw cells were at approximately 4, 6, and $8 \mathrm{~cm}$ below the sediment water interface. Pore water was sampled before application of treatments, and at 10 and 133 days following the addition of the treatments using syringes to apply suction.

Draw-peeper pore-water samples were collected in three separate syringe pulls. The time between syringe pulls varied depending on the length of time it took for pore water to be extracted from each draw-peeper, but was usually less than 5 minutes. The first pull of approximately $3 \mathrm{~mL}$ was allocated to ancillary chemistry and preserved as described for Experiment 1. The second pore-water sample was allocated for MeHg. Samples were collected in pre-weighed $15 \mathrm{~mL}$ polypropylene falcon tubes and preserved with 0.5 -percent $\mathrm{HCl}$. Samples were frozen until analysis. The one-third porewater pull was collected for THg measurement. Samples were collected in pre-weighed $15 \mathrm{~mL}$ polypropylene falcon tubes and preserved with 10-percent BrCl. Samples were refrigerated until analysis.

\section{Experiment 3 (Vegetated Microcosms With Great Pond Snails With No Pore-Water Sampling)}

Hodgdon Pond vegetated intact sediment clumps or "plugs" were collected from fringing wetlands near the outlet of Hodgdon Pond (44 $18^{\prime} 57^{\prime \prime},-68^{\circ} 23^{\prime} 50^{\prime \prime}$ ) on September 10, 2012. The sediment clumps were bowl-shaped and approximately 15 to $20 \mathrm{~cm}$ in width and $15 \mathrm{~cm}$ in height. The sediment was fully saturated and was collected under 2 to $3 \mathrm{~cm}$ of overlying water. The vegetation in the clumps was American bur-reed (Sparganium americanum) and common rush (Juncus effusus). The clumps were brought to the USGS Augusta, Maine, laboratory where the sediment clumps were trimmed to fit and placed in 8 1-gallon acid-washed glass aquaria and covered with approximately $1 \mathrm{~L}$ of Hodgdon Pond water so that the sediment was covered with $5 \mathrm{~cm}$ of water. The microcosms were maintained on a 16 hour light and 8 hour dark schedule. The vegetation initially was clipped to a height of $30 \mathrm{~cm}$. The weight of saturated sediment in each aquaria was between 3.17 and 3.47 kilograms $(\mathrm{kg})$ (average $3.31 \mathrm{~kg}$ ). Water was added regularly to maintain the water level to replace water lost to evaporation and transpiration. The specific conductance of the overlying water never exceeded 170 microsiemens per centimeter.

In Experiment 3, run 1, the microcosms were allowed to equilibrate for 35 days. Following this equilibration period $1.36 \mathrm{~g}$ of ZVI was added to 4 of the microcosms ( 5 times the estimated amount of total $\mathrm{Fe}$ in the sediment to a depth of $3 \mathrm{~cm}$ ) and incorporated into the surface $3 \pm 1 \mathrm{~cm}$ sediment using a glass stirring rod to gently incorporate the ZVI in the sediment around the existing vegetation stems and roots. The other 4 microcosms were maintained as reference treatments and the surface sediment also was stirred in these reference treatments. The microcosms were allowed to equilibrate with the ZVI treatments for 121 days. During this period the water levels were maintained using Hodgdon Pond water or moderately hard water (MOD) composed of sodium bicarbonate $\left(\mathrm{NaHCO}_{3}\right)$, calcium sulfate dihydrate $\left(\mathrm{CaSO}_{4} \cdot 2 \mathrm{H}_{2} \mathrm{O}\right)$, magnesium sulfate $\left(\mathrm{MgSO}_{4}\right)$, and potassium chloride (KCl) (U.S. Environmental Protection Agency, 2002b). The specific conductance of the overlying water never exceeded $170 \mu \mathrm{S} / \mathrm{cm}$ at $25^{\circ} \mathrm{C}$ during this treatment period and the specific conductance of the MOD water was within 20 percent of the Hodgdon Pond water.

Great pond snails (L. stagnalis) were selected for mercury biouptake experiments because they have been used successfully as test organisms to assess uptake of trace 
metals including mercury in laboratory microcosms (Croteau and Luoma, 2009; Croteau and others, 2011; Tessier and others, 2007). Adult snails were provided by Marie-Noële Croteau (U.S. Geological Survey, Menlo Park, California). Snails were reared in the laboratory in MOD described above and fed a diet of romaine lettuce. On February 13, 2013, a cohort of juvenile snails of a restricted size range (shell lengths 10 to 15 millimeters $(\mathrm{mm})$ (mean soft tissue dry weight of $7.8 \pm 0.5$ milligrams [mg]) was assumed based on size and weight relations determined by M.-N. Croteau (U.S. Geological Survey, oral commun., [January 12, 2012]) was transferred to a glass tray and sorted by size to obtain 12 snails of approximately equal sizes for use in each microcosm. The vegetation in the microcosm was clipped to $5 \mathrm{~cm}$ above the aquarium surface. Twelve snails were then placed in each of the 8 microcosms and the microcosms were covered with plastic wrap to prevent snails from escaping. During the period when the snails were maintained in the microcosms no food was added so the snails had a diet of periphyton and detritus. The snails were maintained in the microcosms for a 28-day exposure period after which they were collected and placed in 1-quart glass jars filled with MOD and allowed to depurate for 48 hours. After depuration, the snails were frozen. Partially thawed $L$. stagnalis were dissected to remove the soft tissue that was refrozen and later freeze dried. At the end of the exposure period the surface $3 \pm 1 \mathrm{~cm}$ of sediment was sampled from each microcosm and frozen until it was analyzed. Pore water was not sampled from the mesocosms before or during the exposure period in this experiment.

In Experiment 3, run 2, this experiment was repeated using the same vegetated mesocosms but with doubling the amount of ZVI addition. The reference mesocosms were maintained as in run 1 of this experiment. On March 13, 2013, an additional $1.36 \mathrm{~g}$ of ZVI was added to the previously ZVItreated mesocosms so that at the start of this experiment these mesocosms had received 10 times the estimated amount of total $\mathrm{Fe}$ in the sediment to a depth of $3 \mathrm{~cm}$. The microcosms were maintained on a 16 hour light and 8 hour dark schedule. In Experiment 3, run 2, the equilibration period following the addition of ZVI was reduced to a single day. On March 14, 2013, 10 juvenile snails (shell lengths 10 to $15 \mathrm{~mm}$ ) were placed in each of the 8 microcosms, and the microcosms were covered with plastic wrap to prevent snails from escaping. The snails were maintained in the microcosms for a 25-day exposure period after which they were allowed to depurate for 48 hours and then frozen. Partially thawed L. stagnalis were dissected to remove the soft tissue that was refrozen and later freeze dried. At the end of the exposure period, the surface $3 \pm 1 \mathrm{~cm}$ of sediment was sampled from each microcosm and frozen until it was analyzed.

The sediment samples collected at the end of the snail exposure periods from this experiment were shipped on ice to the USGS Menlo Park laboratory on July 10, 2013. At the USGS Menlo Park laboratory all sediment samples initially were freeze dried and stored in a desiccator before analysis for sediment $\mathrm{MeHg}, \mathrm{Hg}(\mathrm{II})_{\mathrm{R}}$, and iron-speciation. The frozen snail samples from this mesocosm experiment were freeze dried and shipped to the USGS Menlo Park laboratory where they were subsequently stored in a desiccator before analysis for $\mathrm{MeHg}$.

\section{Experiment 4 (Field Mesocosms With Pore- Water Sampling)}

On August 12, 2013, 12 mesocosms were established in the fringing marsh near the outlet of Hodgdon Pond in a line adjacent to and parallel with the outlet channel centered on latitude $44^{\circ} 19^{\prime}$ and longitude $-68^{\circ} 23^{\prime} 50.6^{\prime \prime}$. The treatments were randomly assigned along this line to points that were $2 \mathrm{~m}$ apart. The mesocosms were established in vegetated sites. Polyvinyl chloride cylinders of approximately $38-\mathrm{cm}$ diameter and $39-\mathrm{cm}$ length were driven into the sediment where the water depth was a few centimeters above the sediment surface. To drive the cylinders into the sediment, rubber mallets were used and keyhole saws were used to cut around the outside of the cylinders so that they could penetrate the thick roots and woody detrital materials. The cylinders were driven into sediment to a depth of about $15 \mathrm{~cm}$ deep. Sediment samples were collected from each mesocosm before the application of treatments. GAC was added to four mesocosms, ZVI was added to four mesocosms, and four mesocosms were left untreated as reference treatments. Four mesocosms received $9.8 \mathrm{~g} \mathrm{ZVI} \mathrm{to}$ attain an estimated 8.9 times the amount of total iron present in the top $3 \mathrm{~cm}$ of the sediment. Four mesocosms received $9.1 \mathrm{~g} \mathrm{GAC}$ to attain an estimated concentration of 1.7 percent GAC by dry weight basis in the top $3 \mathrm{~cm}$ of sediment. Four mesocosms were left untreated as reference treatments. The ZVI and GAC were mixed into the sediment to a depth of about $3 \mathrm{~cm}$ and the surface $3 \mathrm{~cm}$ of the reference treatments was similarly mixed but with no additions.

Draw-peepers, as described above, for pore-water sampling were installed vertically in 2 reference, 2 ZVItreated, and $2 \mathrm{GAC}$-treated mesocosms so that the sampling depths were approximately $1.5,3.5,5.5$ and $7.5 \mathrm{~cm}$ below the sediment water interface. Pore-water samples were collected in two separate syringe pulls. The first pull of approximately $3 \mathrm{~mL}$ was allocated to ancillary chemistry and preserved as described for Experiment 1. However, $\mathrm{pH}$ measurements were not collected. The second pore-water sample was allocated for $\mathrm{MeHg}$ and $\mathrm{THg}$. Samples were collected in pre-weighed $15 \mathrm{~mL}$ polypropylene falcon tubes and were flash frozen and preserved with 0.5 -percent $\mathrm{HCl}$ within 6 hours of return to the laboratory. After preservation, all samples were frozen until analysis. After an adequate sample was used for $\mathrm{MeHg}$ analysis, the remaining sample was preserved with $0.5 \mathrm{~mL}$ of $\mathrm{BrCl}$, and refrigerated for $\mathrm{THg}$ analysis.

Pore water was sampled at various depths 25 and 91 days following the addition of the treatments. The surface $3 \mathrm{~cm}$ of sediment was sampled on August 12, 2013, prior the application of ZVI and GAC and 25 and 91 days following the addition of the treatments. In some cases the sample volumes 
were too low to permit analysis. The sediment-pore water distribution coefficient for $\mathrm{MeHg}\left(\mathrm{K}_{\mathrm{D}}[\mathrm{L} / \mathrm{kg}]\right)$ was calculated as the ratio of the dry weight sediment $\mathrm{MeHg}$ concentration to the pore-water $\mathrm{MeHg}$ concentration:

$$
\mathrm{K}_{\mathrm{D}}\left(\frac{L}{\mathrm{~kg}}\right)=\frac{\text { Sediment MeHg concentration }}{\text { Dissolved (pore-water) MeHg concentration }}
$$

The $\mathrm{MeHg} \mathrm{K}_{\mathrm{D}}$ was calculated for the mesocosms that were sampled for pore-water $\mathrm{MeHg}$ concentration at various depths 25 and 91 days following the addition of the treatments.

Sediment samples were flash frozen in the field in $50-\mathrm{mL}$ centrifuge tubes, delivered to the laboratory, semithawed in the refrigerator, homogenized in whirl packs, and then refrozen in their respective 50-mL tubes. Subsamples of these were collected by thawing the sediment in the refrigerator and pouring the slurry into a $15-\mathrm{mL}$ polypropylene falcon tube. These subsamples were freeze dried for $>50$ hours using a Lyph-Lock 4.5 freeze drier.

\section{Experiment 5 (Vegetated Microcosms With Snails)}

On October 14, 2013, Hodgdon Pond vegetated intact sediment clumps were collected from fringing wetlands near the pond outlet and were placed in 121 -gallon glass aquaria and returned to the laboratory. Hodgdon Pond water was added to each aquarium (microcosm) to a depth of approximately $10 \mathrm{~cm}$. The microcosms were maintained on a 16 hour light and 8 hour dark schedule. Treatments were applied and draw-peepers were installed on October 18, 2013. Four mesocosms received $1.4 \mathrm{~g}$ ZVI to attain an estimated 5 times the amount of total $\mathrm{Fe}$ present in the top $3 \mathrm{~cm}$ of the sediment. Four mesocosms received $1.3 \mathrm{~g} \mathrm{GAC}$ to attain an estimated concentration of 0.96 percent GAC by dry weight basis in the top $3 \mathrm{~cm}$ of sediment. Four mesocosms were left untreated as reference treatments. The ZVI and GAC were mixed into the sediment to a depth of about $3 \mathrm{~cm}$ and the surface $3 \mathrm{~cm}$ of the reference treatments was similarly mixed but with no additions. The draw-peepers were installed in two mesocosms that were treated with ZVI, two that were treated with GAC, and in two of the reference treatments.

Great pond snails (L. stagnalis) were reared in the laboratory in MOD and fed a diet of romaine lettuce. On February 7, 2014 (116 days following establishment of the microcosms and 112 days following application of treatments) 10 juvenile snails of a restricted size range (shell lengths 10 to $15 \mathrm{~mm}$ ) were placed in each microcosm. The tops of the aquaria were wrapped with plastic to ensure that the snails did not escape. The snails were removed from the mesocosms on March 20, 2014, after an exposure period of 41 days. The snails were allowed to depurate for 24 hours and were then frozen, before dissecting to remove tissue and the tissue was freeze dried before analysis. At the end of the exposure period, $3 \mathrm{~cm}$ of surface sediment was sampled from each microcosm and frozen until it was analyzed. Pore water was sampled at $2 \mathrm{~cm}$ below the sediment/water interface and sediment (top $3 \mathrm{~cm}$ ) was sampled 125, 154, and 174 days following the addition of the treatments using the same procedures as described for Experiment 4.

\section{Laboratory Analytical Procedures for Experiments 1 and 2}

\section{Total Mercury}

Sediment THg associated with the single field sample collected during November 2011 was assayed in duplicate using a standard USGS approved method (Olund and others, 2004). Approximately $0.2 \mathrm{~g}$ of sediment was initially digested with aqua regia $\left(2 \mathrm{~mL}\right.$ of concentrated $\mathrm{HNO}_{3}$ and $6 \mathrm{~mL}$ of concentrated $\mathrm{HCl}$ ) in Teflon bombs overnight at room temperature. Subsequently, $22 \mathrm{~mL}$ of 5-percent $\mathrm{BrCl}$ was added to each sample, and the bombs were heated to $50{ }^{\circ} \mathrm{C}$ in an oven overnight. Once cooled, a 5-mL subsample was transferred into a precombusted glass container. The digestate was analyzed on an Automated Mercury Analyzer (Tekran Model 2600, Tekran, Inc., Canada), according to EPA method 1631, revision E (U.S. Environmental Protection Agency, 2002). This method is based on the stannous (tin) chloride $\left(\mathrm{SnCl}_{2}\right)$ reduction of $\mathrm{Hg}(\mathrm{II})$ to gaseous $\mathrm{Hg}(0)$, trapping $\mathrm{Hg}(0)$ on goldplated sand, thermal desorption, and quantification of $\mathrm{Hg}(0)$ by way of cold vapor atomic fluorescence spectrometry.

The method detection limit at the level of the Tekran analyzer was 0.10 nanograms per liter (ng/L) of aqueous digest, giving a sediment dry weight detection limit of approximately 0.5 nanograms per gram ( $\mathrm{ng} / \mathrm{g}$ ) (as run), depending on the wet sediment mass digested and its water content. This single sample was assayed with a larger batch of sediment samples from another project. The quality assurance metrics for that batch run included the following: (a) recovery of the certified reference material (PACS 2, marine sediment, THg certified value of 3.04 microgram per gram $(\mu \mathrm{g} / \mathrm{g})$ was 89.9 percent $(n=1)$, (b) matrix spike recovery was $114 \pm 17$ percent $(n=2)$, and (c) the relative percent deviation (RPD) for duplicate analyses was $2.9 \pm 2.6$ percent $(n=3)$.

Pore-water THg was assayed on the November 2011 sample after heated digestion with $\mathrm{BrCl}$ oxidation followed by $\mathrm{SnCl}_{2}$ reduction, purge and trap quantification of gaseous elemental $\mathrm{Hg}^{0}$, as per EPA method 1631 (U.S. Environmental Protection Agency, 2002). Quantification was carried out on an Automated Mercury Analyzer (Tekran Model 2600, Tekran, Inc., Canada), as described above. The quality assurance metrics for that batch run included the following: (a) recovery 
of the certified reference material (NIST 1641d, THg certified value of $15.9 \mathrm{ng} / \mathrm{L}$ ) was 113 percent $(n=1)$, and (b) matrix spike recovery was $96.7 \pm 0.4$ percent $(n=2)$. Because of limited volume, this sample was not assayed in duplicate.

\section{Reactive Mercury}

Sediment $\mathrm{Hg}(\mathrm{II})_{\mathrm{R}}$ is methodologically defined as the fraction of total $\mathrm{Hg}(\mathrm{II})$, that has not been chemically altered (for example, digested, oxidized, or chemically preserved apart from freezing), that is readily reduced to elemental $\mathrm{Hg}(0)$ by an excess of $\mathrm{SnCl}_{2}$ for an exposure time of 15 minutes. This operationally defined parameter was developed as a surrogate measure of the fraction of inorganic $\mathrm{Hg}$ (II) that is most likely available to $\mathrm{Hg}(\mathrm{II})$-methylating bacteria responsible for MeHg production (Marvin-DiPasquale and Cox, 2007; Marvin-DiPasquale and others, 2014). The single whole sediment sample collected during 2011 was assayed in duplicate, with subsample weights of $0.55 \mathrm{~g}$ and $0.81 \mathrm{~g}$. The freeze dried samples from the 2013 field and mesocosm experiments had subsample weights ranging from $0.11-0.83 \mathrm{~g}$. Assay conditions were run as described in Marvin-DiPasquale and Cox, (2007). There is no certified reference material for this assay and matrix spikes are not appropriate because of the operationally defined nature of the assay. Quality controls included bubbler blanks, calibration standards prepared from a NISTcertified commercial $\mathrm{HgCl}_{2}$ stock, and analytical duplicates. The RPD for analytical duplicates was 18.5 percent for the 2011 sample and $6.5 \pm 1.8$ percent $(n=2)$ for the 2013 freeze dried samples.

\section{Methylmercury}

Methylmercury in both sediment and snail tissue was assayed by first digesting in an extractant of 25 percent potassium hydroxide $(\mathrm{KOH})$ in methanol in a $60^{\circ} \mathrm{C}$ oven for 4 hours (Florida Department of Environmental Protection, 2011) followed by ethylation with sodium tetraethyl borate of a diluted subsample in trace metal clean I-Chem vials and quantification on an automated $\mathrm{MeHg}$ analysis system (Brooks Rand Laboratories, Seattle, Washington) using coldvapor atomic fluorescence spectrometry detection. Sediment subsample masses used for analysis were approximately $0.5 \mathrm{~g}$ wet weight for the 2011 whole sediment sample, $0.1 \mathrm{~g}$ dry weight for the 2013 sediment samples, and $0.0015-0.022 \mathrm{~g}$ for the snail tissue. Quality assurance included the following: (a) certified reference material, (b) matrix spikes, (c) analytical duplicates, (d) method blanks, and (e) calibration standards prepared from commercial crystalline methlymercuric chloride and commercial $\mathrm{MeHg}$ standard solution.

The method detection limit at the level of the MERX analyzer is approximately 0.4 picograms of $\mathrm{MeHg}$ (absolute), and the detection limit of any particular sediment or tissue sample is fully dependent on the sample dry mass digested and subsample volume used. No samples were below detection at the level of the MERX analyzer. For sediment samples, the average ( \pm standard deviation) recovery of the certified reference material (CC-580, estuarine sediment, $\mathrm{MeHg}$ certified value of $75 \mathrm{ng} / \mathrm{g}$ ) was $106 \pm 6$ percent ( $n=4$, both batches combined). The average matrix spike recovery was $101 \pm 5$ percent ( $n=8$, both batches combined). The average RPD for duplicate analyses was $4.9 \pm 5.3$ percent ( $n=4$, both batches combined).

For snail samples, the average ( \pm standard deviation) recovery of the certified reference material (TORT-2, Lobster Hepatopancreas, MeHg certified value of $152 \mathrm{ng} / \mathrm{g}$ ) was $92 \pm 1$ percent $(n=2)$. The average matrix spike recovery was $98 \pm 4$ percent $(n=4)$. The average RPD for duplicate analyses was $2.6 \pm 1.5$ percent $(n=2)$.

Pore-water $\mathrm{MeHg}$ was assayed on the November 2011 sample after distillation (DeWild and others, 2001), followed by ethylation and quantification on an automated MeHg analysis system (Brooks Rand Laboratories, Seattle, Washington), as described above. The quality assurance metrics for that batch run included matrix spike recovery, which was $105 \pm 11$ percent $(n=3)$. Due to limited volume, this sample was not assayed in duplicate, however RPD values for other samples in that batch run were $14.2 \pm 13.0$ percent $(n=3)$. Commercial certified reference material was not available for this assay.

\section{Sediment Bulk Density, Percent Dry Weight, Porosity, and Organic Content}

Sediment bulk density was assayed on the 2011 sediment sample first, precisely determining the volume and weight of $n=5$ replicate samples. The relative percent standard deviation (RPSD) of this analysis was 1.0 percent. Sediment percent dry weight was then determined on duplicate 3 -g subsamples (wet weight) by weighing before and after oven drying at $105^{\circ} \mathrm{C}$ until constant weight was achieved. The relative percent difference (RPD) of this analysis was 1.7 percent. Subsequently, the two samples were then combusted at $450{ }^{\circ} \mathrm{C}$ for 4 hours and reweighed for a percent LOI determination. The RPD of this analysis was 2.8 percent.

\section{Total Reduced Sulfur}

Sediment total reduced sulfur (TRS) analysis was carried out on the 2011 whole sediment sample using a modified version of a single-step distillation procedure using heated acid and chromium for reduction of sulfur to hydrogen sulfide $\left(\mathrm{H}_{2} \mathrm{~S}\right)$ (Fossing and Jørgensen, 1989), where the evolved $\mathrm{H}_{2} \mathrm{~S}$ gas is precipitated as zinc sulfide $(\mathrm{ZnS})$ in a zinc acetate solution. The resulting $\mathrm{ZnS}$ precipitate was subsequently subsampled and assayed using spectrophotometric analysis (Cline, 1969). Duplicate subsamples of $1.0 \mathrm{~g}$ (wet weight) were analyzed. Calibration standards $(\mathrm{ZnS})$ and matrix spike solutions were prepared by precipitating a known weight reagent grade sodium sulfide $\left(\mathrm{Na}_{2} \mathrm{~S}\right)$ crystal in 10 percent zincacetate in anoxic conditions. The $\mathrm{ZnS}$ matrix spike recovery 
was 90 percent $(n=1)$. Certified reference material for the TRS assay is not available commercially. The RPD for duplicate analysis was 3.5 percent.

\section{Iron Speciation}

Sediment iron speciation was carried out both on the 2011 whole sediment sample and the 2013 freeze dried field and mesocosm samples. Three Fe-fractions (acid-extractable ferrous iron $\left(\mathrm{Fe}(\mathrm{II})_{\mathrm{AE}}\right)$, amorphous (poorly crystalline) ferric iron (Fe(III)a), and crystalline ferric iron (Fe(III)c) were assayed as described in Marvin-DiPasquale and others (2009a,b). Sediment subsample masses used for analysis were approximately $0.5 \mathrm{~g}$ wet weight for the 2011 whole sediment sample (assayed in duplicate) and $0.07-0.21 \mathrm{~g}$ dry weight for the 2013 freeze dried sediment samples. The typical detection limit for each Fe-fraction is approximately $0.02 \mu \mathrm{g} / \mathrm{mL}$ at the level of the spectrophotometric analysis. Certified reference material for the various $\mathrm{Fe}$-species is not commercially available. Calibration standards of $\mathrm{FeSO}_{4}$ were prepared in a solution of $0.25 \mathrm{M}$ hydroxylamine-HCl to inhibit Fe(II) oxidation to $\mathrm{Fe}(\mathrm{III})$. The average RPD for duplicate assays associated with each of the three Fe fractions in sediment was 15.1 \pm 7.7 percent $(n=3)$ for $\mathrm{Fe}(\mathrm{III})_{\mathrm{AE}}, 8.2 \pm 1.3$ percent $(n=2)$ for $\mathrm{Fe}(\mathrm{III}) \mathrm{a}$, and $2.1 \pm 0.8$ percent $(n=2)$ for $\mathrm{Fe}(\mathrm{III}) \mathrm{c}$.

\section{Laboratory Analytical Procedures for Pore Water Collected From Experiments 1, 2, 4, and 5 and Sediment From Experiments 4 and 5}

Analysis of pore water for total mercury was carried out with a Tekran 2600 cold-vapor atomic fluorescence spectrometer (CVAFS) following EPA method 1631 and using hydroxylamine hydrochloride $\left(\mathrm{NH}_{2} \mathrm{OH}-\mathrm{HCl}\right)$ for oxidant pre-reduction and acidified $\mathrm{SnCl}_{2}$ for instrument reduction (U.S. Environmental Protection Agency, 2002a). All pore-water mercury samples were analyzed in clean room conditions using trace metal grade reagents and following appropriate and well-documented sample handling protocols (Mason and others, 1998; U.S. Environmental Protection Agency, 2002a).

Sediment samples from Experiments 4 and 5 were analyzed for THg using a Direct Mercury Analyzer (DMA) using thermal decomposition, amalgamation, and atomic absorption spectrophotometry following EPA Method 7473 (U.S. Environmental Protection Agency, 2007).

$\mathrm{MeHg}$ analysis for sediment and pore water was carried out with a Tekran 2700 CVAFS following EPA Method 1630 (U.S. Environmental Protection Agency, 1998) with modifications for sediment digestion methods (personal commun., Evangelos Kakouros, U.S. Geological Survey, Menlo Park, Calif.). Sample preparation involved the following processes: distillation (for pore waters), digestion (for sediment) ethylation, chromatographic separation, and thermal decomposition.

Sulfide was determined colorimetrically following Cline (1969) (detection limit 10 micromoles per liter $(\mu \mathrm{mol} / \mathrm{L})$. $\mathrm{Fe}(\mathrm{II})$ was determined colorimetrically following Stookey (1970) (detection limit $5 \mu \mathrm{mol} / \mathrm{L}$ ). $\mathrm{pH}$ was measured with a portable gel probe (Accumet Gel-Filled Combination Electrode with an Orion Model 290Aplus meter). DOC was determined using a TOC analyzer (OI Corporation 1010; detection limit 0.5 parts per million [ppm]).

\section{Results of the Laboratory and Field Experiments}

The results of the laboratory and field experiments are described in 6 sections. The first section describes the chemical characteristics of the littoral sediment and pore water. The second and third sections describe the effects of ZVI on pore water chemistry from littoral and profundal sediment. The fourth section describes the effects of ZVI on pore sediment chemistry and the uptake of mercury in snails from Experiment 3. The fifth section describes the effects of ZVI and GAC on pore-water and sediment chemistry in the field mesocosms. The final section describes the effects of ZVI and GAC on sediment chemistry and uptake of mercury in snails in Experiment 5.

\section{Chemical Characteristics of Littoral Sediment and Sediment Pore Water}

Selected chemical characteristics of littoral sediment collected from the top $15 \mathrm{~cm}$ in a wetland fringing the eastern shore of Hodgdon Pond indicate this material to be rich in organic matter ( $\mathrm{LOI}=46.5$ percent; table 1$)$. The sediment had $8.36 \mu \mathrm{mol}$ of total reduced sulfur $\mathrm{gdw}^{-1}$ and $2.0 \mathrm{mg} \mathrm{gdw}^{-1}$ total $\mathrm{Fe}$ in the $\mathrm{Fe}(\mathrm{II})_{\mathrm{AE}}, \mathrm{Fe}(\mathrm{III}) \mathrm{a}$ and $\mathrm{Fe}(\mathrm{II}) \mathrm{c}$ (crystalline) fraction combined, most of which was $\mathrm{Fe}(\mathrm{II})_{\mathrm{AE}}$ with minor amounts in the other forms. The sediment contained $90.5 \mathrm{ng}$ $\mathrm{gdw}^{-1} \mathrm{THg}, 1.36 \mathrm{ng} \mathrm{gdw}^{-1} \mathrm{Hg}(\mathrm{II})_{\mathrm{R}}$, and $2.42 \mathrm{ng} \mathrm{gdw}^{-1} \mathrm{MeHg}$. Reactive mercury was 1.5 percent of THg and $\mathrm{MeHg}$ was 2.68 percent of THg. This sediment THg concentration was substantially higher than that reported for four vernal pools at Acadia National Park (Loftin and others, 2012) but the $\mathrm{MeHg}$ concentrations are similar to those observed in a vernal pool in Massachusetts (Benoit and others, 2013). The pore water extracted from this sediment contained $49.3 \mathrm{ng} / \mathrm{L} \mathrm{THg}$ and $0.76 \mathrm{ng} / \mathrm{L} \mathrm{MeHg}$ and $\mathrm{MeHg}$ was 1.54 percent of THg in pore water. 
Table 1. Chemical characteristics of littoral sediment and pore water extracted from sediment from wetlands fringing Hodgdon Pond, Mount Desert Island, Maine.

$\left[\%\right.$, percent; wt, weight; $\mu$ mol, micromole; $\mu \mathrm{m}$, micrometer; $\mathrm{gdw}^{-1}$, per gram dry weight of sediment; S, sulfur; mg, milligram; ng, nanogram; ng L-1 ${ }^{-1}$, nanogram per liter; $\mathrm{Fe}(\mathrm{II})_{\mathrm{AE}}$, acid-extractable divalent iron or $\mathrm{Fe}^{2+} ; \mathrm{Fe}(\mathrm{III})$, trivalent iron or $\mathrm{Fe}^{3+} ; \mathrm{Hg}$, mercury; $\mathrm{Hg}(\mathrm{II})_{\mathrm{R}}$, reactive $\mathrm{Hg}$; $\mathrm{THg}$, total $\mathrm{Hg}$; MeHg, methyl mercury; <, less than]

\begin{tabular}{|c|c|c|}
\hline Constituent & Units & Value \\
\hline $\begin{array}{l}\text { Sediment loss on ignition (LOI) as } \\
\text { percentage of dry wt }\end{array}$ & $(\%)$ & 46.5 \\
\hline Sediment grain size $<64 \mu \mathrm{m}$ & $(\%)$ & 63.4 \\
\hline Sediment total reduced S (TRS) & $\left(\mu \mathrm{mol} \mathrm{gdw} \mathrm{gd}^{-1}\right)$ & 8.36 \\
\hline Sediment acid-extractable $\mathrm{Fe}(\mathrm{II})_{\mathrm{AE}}$ & $\left(\mathrm{mg} \mathrm{gdw}^{-1}\right)$ & 1.84 \\
\hline Sediment amorphous Fe(III)a & $\left(\mathrm{mg} \mathrm{gdw}^{-1}\right)$ & $<0.08$ \\
\hline Sediment crystalline $\mathrm{Fe}(\mathrm{III}) \mathrm{c}$ & $\left(\mathrm{mg} \mathrm{gdw}{ }^{-1}\right)$ & 0.09 \\
\hline Sediment $\mathrm{THg}$ & $\left(\mathrm{ng} \mathrm{gdw}^{-1}\right)$ & 90.50 \\
\hline Sediment $\operatorname{Hg}(\mathrm{II})_{\mathrm{R}}$ & $\left(\right.$ ng gdw $\left.{ }^{-1}\right)$ & 1.36 \\
\hline Sediment $\mathrm{MeHg}$ & $\left(\mathrm{ng} \mathrm{gdw}^{-1}\right)$ & 2.42 \\
\hline Sediment $\mathrm{Hg}(\mathrm{II})_{\mathrm{R}}$ as a percentage of $\mathrm{THg}$ & $(\%)$ & 1.50 \\
\hline Sediment $\mathrm{MeHg}$ as a percentage of $\mathrm{THg}$ & $(\%)$ & 2.68 \\
\hline Pore-water $\mathrm{MeHg}$ & $\left(\mathrm{ng} \mathrm{L}^{-1}\right)$ & 0.76 \\
\hline Pore-water $\mathrm{THg}$ & $\left(n g L^{-1}\right)$ & 49.30 \\
\hline Pore-water $\mathrm{MeHg}$ as a percentage of $\mathrm{THg}$ & $(\%)$ & 1.54 \\
\hline
\end{tabular}

\section{Effects of Zero-Valent Iron on Pore-Water Chemistry From Littoral Sediment (Experiment 1)}

The addition of ZVI to blended sediment maintained in microcosms in the laboratory resulted in an increase in $\mathrm{Fe}(\mathrm{II})$ concentrations in the 50 times native total Fe treatments and an increase in $\mathrm{pH}$ in the 5 and 50 times native total iron treatments in the surface sediment where treatments had been applied (figs. $2 A$ and $B$; table 2). No statistical comparison is warranted because of the small sample size; therefore these increases should be considered qualitative indications of changes in pore-water chemistry. These differences in $\mathrm{Fe}(\mathrm{II})$ concentrations and $\mathrm{pH}$ were observed at 2- and 4-cm depths but not at 6- and 8 -cm depths (figs. $2 C$ and $D$ ). Porewater $\mathrm{THg}$ and $\mathrm{MeHg}$ concentrations were below detection limits (approximately $0.10 \mathrm{ng} / \mathrm{L}$ for $\mathrm{THg}$ and 0.4 picograms [absolute] for $\mathrm{MeHg}$ ) at all depths and for all sampling times. Dissolved hydrogen sulfide concentrations were measured before ZVI treatment and generally determined to be in the range of 0.5 to $4 \mu \mathrm{mol} / \mathrm{L}$. Initial DOC concentrations 12 days after the microcosms were established were in the range of 27 to 52 ppm but by 42 days after establishment had declined to 20 and $28 \mathrm{ppm}$ (table 2). Following ZVI application, DOC concentrations changed little except at the 2- and 4-cm depths in the 50 times native Fe treatment where they declined to the range of 15 to $20 \mathrm{ppm}$ indicating possible adsorption to $\mathrm{Fe}$ in these treatments. Substantial seasonal variation in $\mathrm{Fe}$ (II) and sulfide concentrations in pore water has been reported for organic matter-rich littoral lake sediment in Michigan (Koretsky and others, 2006). These seasonal variations suggest that temperature and biological activity substantially affect concentrations so that the concentrations measured in these unvegetated microcosms in the laboratory are not necessarily representative of field conditions.

\section{Effects of Zero-Valent Iron on Pore-Water Chemistry From Profundal Sediment (Experiment 2)}

In this experiment, the concentration of Fe(II) varied from 0.16 to $2.0 \mu \mathrm{mol} / \mathrm{L}$ in the overlying water before application of the ZVI treatment and Fe(II) varied from 4 to $27 \mu \mathrm{mol} / \mathrm{L}$ in the pore water from 1 to $7 \mathrm{~cm}$ below the sediment water interface (table 3 ). $\mathrm{pH}$ in the pore water varied from 5.1 to 6.1 , increasing with depth below the surface the sediment water interface. No consistent change in $\mathrm{pH}$ was observed 10 days after ZVI application. Pore-water $\mathrm{THg}$ and $\mathrm{MeHg}$ were not detected, were below detection limit, or were only slightly above detection limits before and after ZVI treatment applications. In this experiment a different type of pore-water sampler (draw-peeper) was used compared with Experiment 1 where Rhizon samplers were used and differences in sampler types could affect the pore water sampled. Similarly, it was not possible to ensure that the samplers were always sampling from the same depths below the sediment water interface because of variability in the surface topography and sediment density among replicate microcosms. Additionally, the sediment water interface was observed to migrate upwards in some instances as the surface sediment became less dense and more of a floc. These differences indicate the need for caution in comparing porewater chemistry between experiments and even throughout time in any single experiment.

\section{Effects of Zero-Valent Iron on Sediment Chemistry and Uptake of Mercury in Snails Using Vegetated Littoral Sediment (Experiment 3)}

The application of ZVI to vegetated littoral sediment from wetlands fringing Hodgdon Pond maintained in glass aquaria resulted in an increase in surficial (top $3 \mathrm{~cm}$ ) sediment $\mathrm{MeHg}$ and no change in snail $\mathrm{MeHg}$ (table 4). For the 5 times native $\mathrm{Fe}$ treatment the concentration of $\mathrm{Fe}(\mathrm{II})_{\mathrm{AE}}$ in the surficial sediment approximately doubled and the concentrations of $\mathrm{Fe}(\mathrm{III}) \mathrm{a}, \mathrm{Fe}(\mathrm{III}) \mathrm{c}$, and total Fe increased by factors of 3.7, 15, and 5.0, respectively. These differences were statistically 

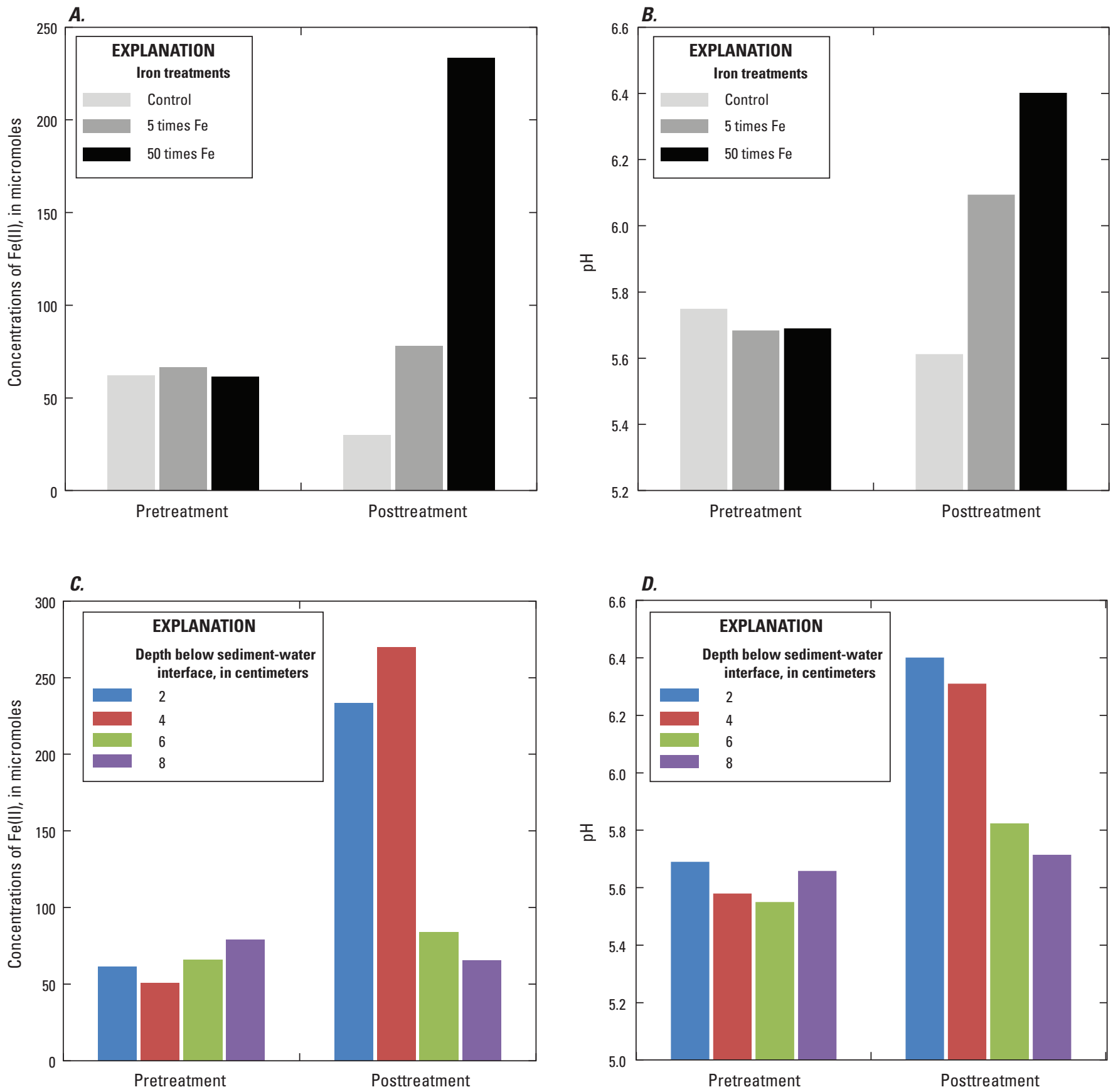

Figure 2. Pore water concentration of $A$, ferrous iron for 5 and 50 times iron treatments, $B, \mathrm{pH}$ for 5 and 50 times iron treatments, $C$, ferrous iron collected from $2,4,6$, and 8 centimeters depth below the sediment-water interface, and $D$, pH collected from 2, 4, 6, and 8 centimeters depth below the sediment-water interface. Fe(II), divalent iron. 
Table 2. Pore-water chemistry from laboratory microcosms with blended littoral sediment (Experiment 1) from Mount Desert Island, Maine.

[Each value is the average of two samples. If the value was less than the minimum detection limit (MDL), then one-half the MDL was used to compute the average; MDL varied among analysis dates. Fe(II), divalent iron; DOC, dissolved organic carbon; cm, centimeter; $\mu \mathrm{M}$, micromolar; ppm, parts per million; Fe, iron; NA, not analyzed]

\begin{tabular}{|c|c|c|c|c|c|}
\hline Treatment & $\begin{array}{c}\text { Depth } \\
\text { cm }\end{array}$ & $\begin{array}{c}\mathrm{Fe}(\mathrm{II}) \\
\mu \mathrm{mol} / \mathrm{L}\end{array}$ & $\begin{array}{l}\text { Sulfide } \\
\text { pmol/L }\end{array}$ & $\begin{array}{l}\text { DOC } \\
\text { ppm }\end{array}$ & pH \\
\hline \multicolumn{6}{|c|}{ 2/14/2012 12 days postestablishment } \\
\hline MDL & & 1.29 & 0.59 & 1.11 & \\
\hline Reference & 2 & 41.38 & 1.91 & 39.37 & 5.42 \\
\hline Reference & 4 & 66.27 & 2.89 & 36.67 & 5.63 \\
\hline Reference & 6 & 115.70 & 2.66 & 43.58 & 5.51 \\
\hline Reference & 8 & 138.60 & 1.39 & 48.02 & 5.42 \\
\hline 5 times $\mathrm{Fe}$ & 2 & 54.99 & 2.71 & 32.01 & 5.45 \\
\hline 5 times $\mathrm{Fe}$ & 4 & 65.46 & 0.39 & 44.38 & 5.28 \\
\hline 5 times $\mathrm{Fe}$ & 6 & 72.59 & 2.23 & 47.70 & 5.45 \\
\hline 5 times $\mathrm{Fe}$ & 8 & 90.94 & 0.08 & 52.30 & 5.35 \\
\hline 50 times $\mathrm{Fe}$ & 2 & 65.56 & 3.79 & 30.48 & 5.52 \\
\hline 50 times $\mathrm{Fe}$ & 4 & 89.67 & 2.79 & 27.13 & 5.46 \\
\hline 50 times $\mathrm{Fe}$ & 6 & 122.09 & 0.84 & 39.19 & 5.39 \\
\hline 50 times $\mathrm{Fe}$ & 8 & 123.75 & 0.30 & 45.52 & 5.35 \\
\hline \multicolumn{6}{|c|}{ 3/15/2012 42 days postestablishment } \\
\hline MDL & & 0.50 & 0.59 & 1.11 & \\
\hline Reference & 2 & 60.72 & NA & 27.10 & 5.69 \\
\hline Reference & 4 & 66.38 & NA & 23.19 & 5.84 \\
\hline Reference & 6 & 75.89 & NA & 23.17 & 5.77 \\
\hline Reference & 8 & 79.65 & NA & 27.95 & 5.89 \\
\hline 5 times $\mathrm{Fe}$ & 2 & 66.39 & NA & 22.80 & 5.95 \\
\hline 5 times $\mathrm{Fe}$ & 4 & 67.22 & NA & 19.50 & 5.97 \\
\hline 5 times $\mathrm{Fe}$ & 6 & 81.72 & NA & 23.23 & 6.17 \\
\hline 5 times $\mathrm{Fe}$ & 8 & 81.69 & NA & 23.63 & 5.85 \\
\hline 50 times $\mathrm{Fe}$ & 2 & 45.29 & NA & 26.60 & 5.99 \\
\hline 50 times $\mathrm{Fe}$ & 4 & 58.52 & NA & 24.23 & 5.78 \\
\hline 50 times $\mathrm{Fe}$ & 6 & 77.68 & NA & 23.16 & 5.80 \\
\hline 50 times $\mathrm{Fe}$ & 8 & 82.52 & NA & 24.17 & 5.76 \\
\hline \multicolumn{6}{|c|}{ 3/26/2012 53 days postestablishment } \\
\hline MDL & & 1.76 & 0.10 & 1.11 & \\
\hline Reference & 2 & 62.16 & 0.45 & 23.62 & 5.76 \\
\hline Reference & 4 & 66.63 & 2.67 & 21.82 & 5.75 \\
\hline Reference & 6 & 69.89 & 0.39 & 21.82 & 5.64 \\
\hline Reference & 8 & 79.73 & 0.51 & 24.68 & 5.63 \\
\hline 5 times $\mathrm{Fe}$ & 2 & 66.59 & 1.62 & 20.29 & 5.69 \\
\hline 5 times $\mathrm{Fe}$ & 4 & 64.07 & 2.38 & 21.16 & 5.81 \\
\hline 5 times $\mathrm{Fe}$ & 6 & 79.21 & 4.08 & 27.55 & 5.74 \\
\hline 5 times $\mathrm{Fe}$ & 8 & 82.39 & 4.09 & 24.47 & 5.58 \\
\hline 50 times $\mathrm{Fe}$ & 2 & 61.42 & 1.74 & 20.28 & 5.69 \\
\hline 50 times $\mathrm{Fe}$ & 4 & 50.97 & 2.83 & 20.51 & 5.60 \\
\hline 50 times $\mathrm{Fe}$ & 6 & 65.87 & 1.75 & 19.84 & 5.56 \\
\hline 50 times $\mathrm{Fe}$ & 8 & 79.12 & 1.64 & 22.53 & 5.66 \\
\hline
\end{tabular}

\begin{tabular}{|c|c|c|c|c|c|}
\hline Treatment & $\begin{array}{c}\text { Depth } \\
\text { cm }\end{array}$ & $\begin{array}{c}\mathrm{Fe}(\mathrm{II}) \\
\mu \mathrm{mol} / \mathrm{L}\end{array}$ & $\begin{array}{l}\text { Sulfide } \\
\mu \mathrm{mol} / \mathrm{L}\end{array}$ & $\begin{array}{l}\text { DOC } \\
\text { ppm }\end{array}$ & pH \\
\hline \multicolumn{6}{|c|}{ 4/17/2012 22 days posttreatment } \\
\hline MDL & & 0.30 & 0.10 & 1.11 & \\
\hline Reference & 1.50 & 5.68 & NA & 20.11 & 5.55 \\
\hline Reference & 2 & 39.83 & NA & 23.47 & 5.79 \\
\hline Reference & 4 & 60.35 & NA & 31.09 & 5.77 \\
\hline Reference & 6 & 67.58 & NA & 26.68 & 5.75 \\
\hline Reference & 8 & 67.85 & NA & 26.57 & 5.68 \\
\hline 5 times $\mathrm{Fe}$ & 1.50 & 13.28 & NA & 15.42 & 6.02 \\
\hline 5 times $\mathrm{Fe}$ & 2 & 71.77 & NA & 20.37 & 5.94 \\
\hline 5 times $\mathrm{Fe}$ & 4 & 91.45 & NA & 25.72 & 5.86 \\
\hline 5 times $\mathrm{Fe}$ & 6 & 66.91 & NA & 28.26 & 5.71 \\
\hline 5 times $\mathrm{Fe}$ & 8 & 82.95 & NA & 28.83 & 5.60 \\
\hline 50 times $\mathrm{Fe}$ & 1.50 & 25.27 & NA & 14.89 & 6.62 \\
\hline 50 times $\mathrm{Fe}$ & 2 & 263.63 & NA & 16.18 & 6.39 \\
\hline 50 times $\mathrm{Fe}$ & 4 & 234.56 & NA & 19.04 & 6.42 \\
\hline 50 times $\mathrm{Fe}$ & 6 & 84.10 & NA & 27.28 & 5.92 \\
\hline 50 times $\mathrm{Fe}$ & 8 & 66.16 & NA & 25.12 & 5.78 \\
\hline \multicolumn{6}{|c|}{ 5/7/2012 42 days posttreatment } \\
\hline MDL & & 0.30 & 0.10 & 1.11 & \\
\hline Reference & 1.50 & 2.75 & NA & 18.43 & 5.57 \\
\hline Reference & 2 & 30.03 & NA & 20.29 & 5.62 \\
\hline Reference & 4 & 57.01 & NA & 24.10 & 5.68 \\
\hline Reference & 6 & 64.19 & NA & 25.85 & 5.59 \\
\hline Reference & 8 & 72.65 & NA & 26.73 & 5.60 \\
\hline 5 times $\mathrm{Fe}$ & 1.50 & 3.69 & NA & 14.42 & 5.93 \\
\hline 5 times $\mathrm{Fe}$ & 2 & 78.19 & NA & 17.21 & 6.10 \\
\hline 5 times $\mathrm{Fe}$ & 4 & 88.34 & NA & 22.32 & 5.80 \\
\hline 5 times $\mathrm{Fe}$ & 6 & 64.35 & NA & 25.11 & 5.82 \\
\hline 5 times $\mathrm{Fe}$ & 8 & 81.43 & NA & 29.36 & 5.61 \\
\hline 50 times $\mathrm{Fe}$ & 1.50 & 6.02 & NA & 10.75 & 6.49 \\
\hline 50 times $\mathrm{Fe}$ & 2 & 233.46 & NA & 14.09 & 6.41 \\
\hline 50 times $\mathrm{Fe}$ & 4 & 270.00 & NA & 15.92 & 6.31 \\
\hline 50 times $\mathrm{Fe}$ & 6 & 83.83 & NA & 23.75 & 5.83 \\
\hline 50 times $\mathrm{Fe}$ & 8 & 65.63 & NA & 27.08 & 5.72 \\
\hline
\end{tabular}


Table 3. Pore-water chemistry from laboratory microcosms with profundal sediment (Experiment 2) from Mount Desert Island, Maine.

[Each value is the average of two samples. If the value was less than the minimum detection limit (MDL), then one-half the MDL was used to compute the average; MDL varied among analysis dates. Fe(II), divalent iron; THg, total mercury; MeHg, methyl mercury; cm, centimeter; $\mu \mathrm{M}$, micromolar; ng L ${ }^{-1}$, nanograms per liter; Fe, iron; NA, not analyzed]






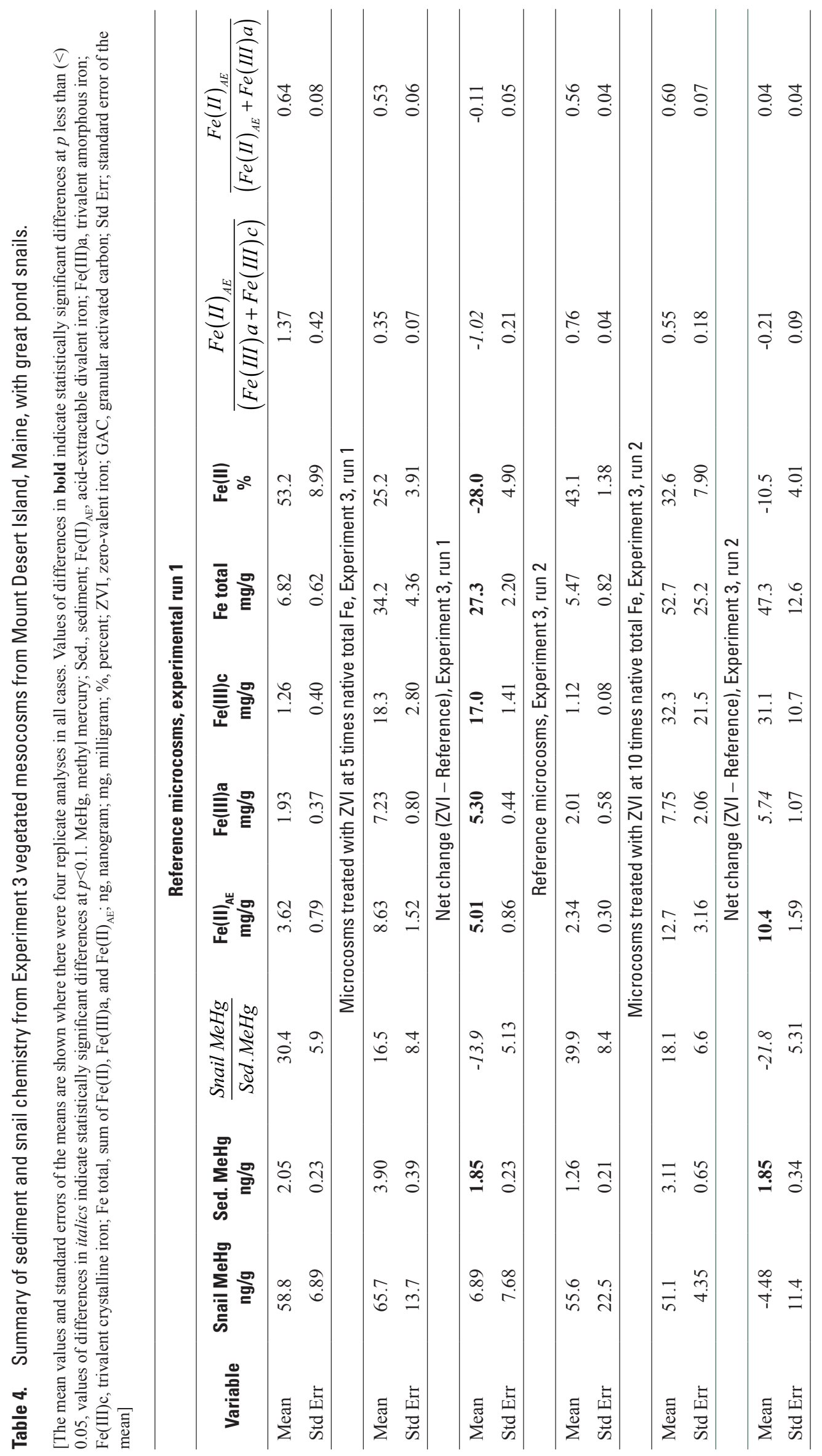


significant ( $p$ less than $[<] 0.01) . \mathrm{Fe}(\mathrm{II})_{\mathrm{AE}}$ as a proportion of total $\mathrm{Fe}$ increased from 25 to 53 percent in the ZVI-treated sediment compared with the reference treatments. Concentrations of $\mathrm{Fe}(\mathrm{II})_{\mathrm{AE}}, \mathrm{Fe}(\mathrm{III}) \mathrm{c}$, and total $\mathrm{Fe}$ increased substantially more for the 10 times native $\mathrm{Fe}$ treatment by factors of 5 , 9.6, and 29, but Fe(III)a increased by a very similar factor to what was observed in the 5 times native Fe treatment. For the 10 times native Fe treatment the amount of $\mathrm{Fe}(\mathrm{II})_{\mathrm{AE}}$ as a proportion of total Fe decreased from 43 to 33 percent in the ZVI-treated sediment compared with the reference treatments.

In this experiment with vegetated littoral sediment, when all treatments were combined, the sediment $\mathrm{MeHg}$ concentration correlated positively with the Fe(III) a concentration ( $\mathrm{r}$ squared $\left.\left[\mathrm{R}^{2}\right]=0.76\right)$ and the regression between these two variables was statistically significant $(p<0.001)$ (fig. $3 A$ ). Similarly, sediment $\mathrm{MeHg}$ concentration was positively correlated with $\mathrm{Fe}(\mathrm{II})_{\mathrm{AE}}$ concentration $\left(\mathrm{R}^{2}=0.39\right)$ and the regression between these two variables also was statistically significant $(p<0.01)$ (fig. $3 B)$. The $\mathrm{MeHg}$ concentration in snail tissue was positively related to the amount of sediment $\mathrm{MeHg}$ but the regression was not statistically significant. Snail tissue $\mathrm{MeHg}$ was not related to the concentration of any iron species.

The results from the two separate experimental runs with 5 times total $\mathrm{Fe}$ in the first run and 10 times total $\mathrm{Fe}$ in the second run (table 4 ) were similar in that the concentration of MeHg in snail tissue was unaffected by the ZVI treatment regardless of the amount of ZVI added. In both cases, the $\mathrm{MeHg}$ concentration in the sediment was increased compared with the reference treatment.

\section{Effects of Zero-Valent Iron and Granular Activated Carbon Treatments on Pore-Water and Sediment Chemistry in Field Mesocosms (Experiment 4)}

There were no statistically significant $(p<0.05)$ differences in the concentrations of $\mathrm{MeHg}, \mathrm{Fe}(\mathrm{II})$ or dissolved hydrogen sulfide in pore water between the treated mesocosms and the reference mesocosms in Experiment 4 at 25 or 91 days after treatment application for any of the depths sampled (fig. 4). However, the concentration of $\mathrm{MeHg}$ in pore water on September 6, 2013 (25 days after application of treatments) was lower, but not significantly, in the GACtreated mesocosms than in the reference mesocosms for the average concentration of $\mathrm{MeHg}$ in samples collected at the 2 and $4 \mathrm{~cm}$ depths $(0.1<p<0.12)$ (fig. 5). No statistically significant differences $(p<0.05)$ were observed in porewater concentrations of $\mathrm{MeHg}$, hydrogen sulfide, or $\mathrm{Fe}(\mathrm{II})$ between samplings 25 and 91 days after application of ZVI and GAC treatments, but the reference mesocosms indicated a significant decrease in pore-water $\mathrm{MeHg}$ between the two sampling dates (fig. 4).
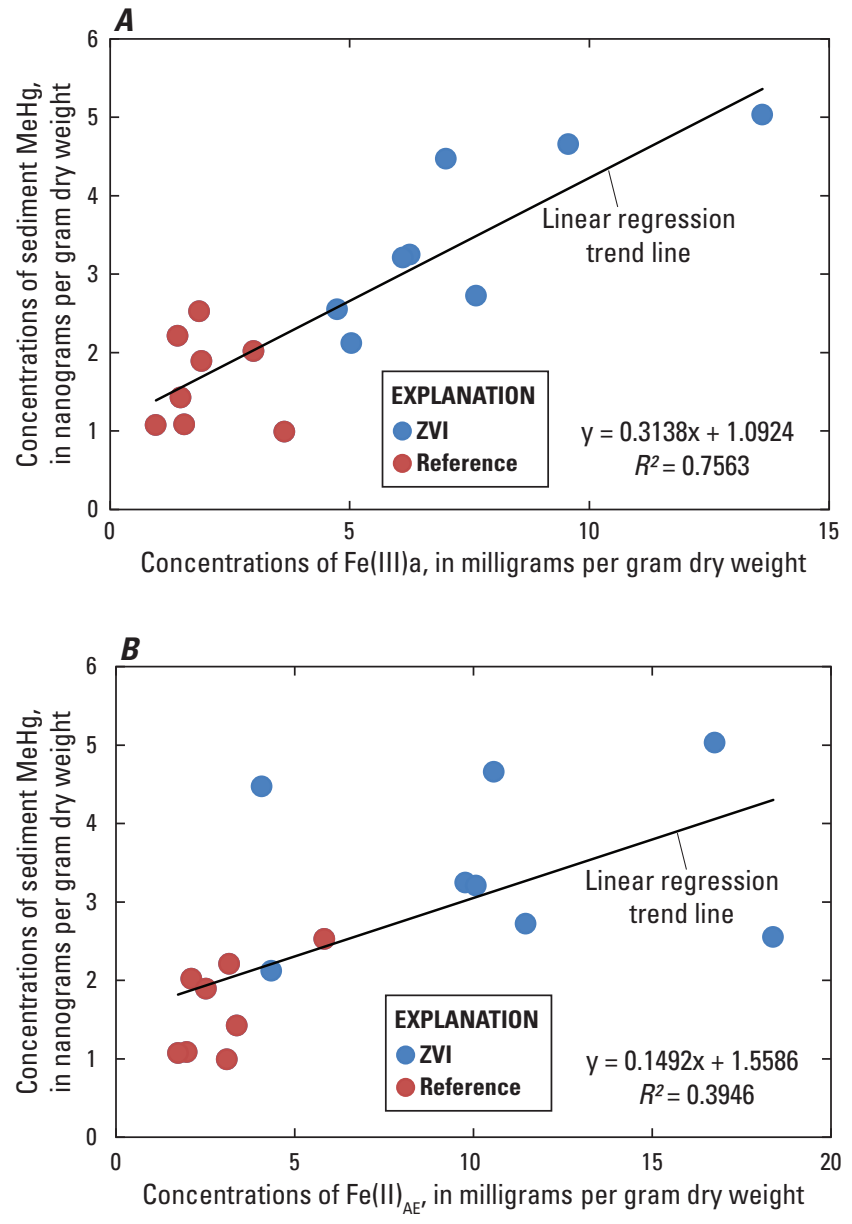

Figure 3. The relation between concentrations of $A$, sediment methylmercury ( $\mathrm{MeHg}$ ) and amorphous trivalent iron ( $\mathrm{Fe}(\mathrm{III}) \mathrm{a}$ ) and $B$, sediment $\mathrm{MeHg}$ and acid-extractable divalent iron $\left(\mathrm{Fe}(\mathrm{II})_{\mathrm{AE}}\right)$, Experiment 3 for Mount Desert Island, Maine, for zero-valent iron (ZVI) treatment and untreated (reference) samples. $\mathrm{R}^{2}$, r squared; $\mathrm{mg} / \mathrm{g} \mathrm{dwt}$, milligram per gram dry weight.

No statistically significant differences were observed in sediment THg, MeHg, or MeHg:THg ratio among mesocosms on August 12, 2013, before the application of ZVI and GAC treatments (data not shown). No significant differences were observed in sediment $\mathrm{THg}$, $\mathrm{MeHg}$, or $\mathrm{MeHg}$ : $\mathrm{THg}$ ratio between treatments or in comparison with the pretreatment condition when mesocosms were resampled on September 6, 2013 (fig. 6). When mesocosms were resampled on November 11, 2013 (91 days posttreatment) THg was unchanged but $\mathrm{MeHg}$ and $\mathrm{MeHg}: \mathrm{THg}$ ratio decreased significantly $(p<0.05)$ on both the ZVI-treated and reference plots. There was a trend towards decreasing $\mathrm{MeHg}$ and MeHg:THg ratio on the GAC-treated plots but the decreases were not significant $(0.1<p<0.12)$. 

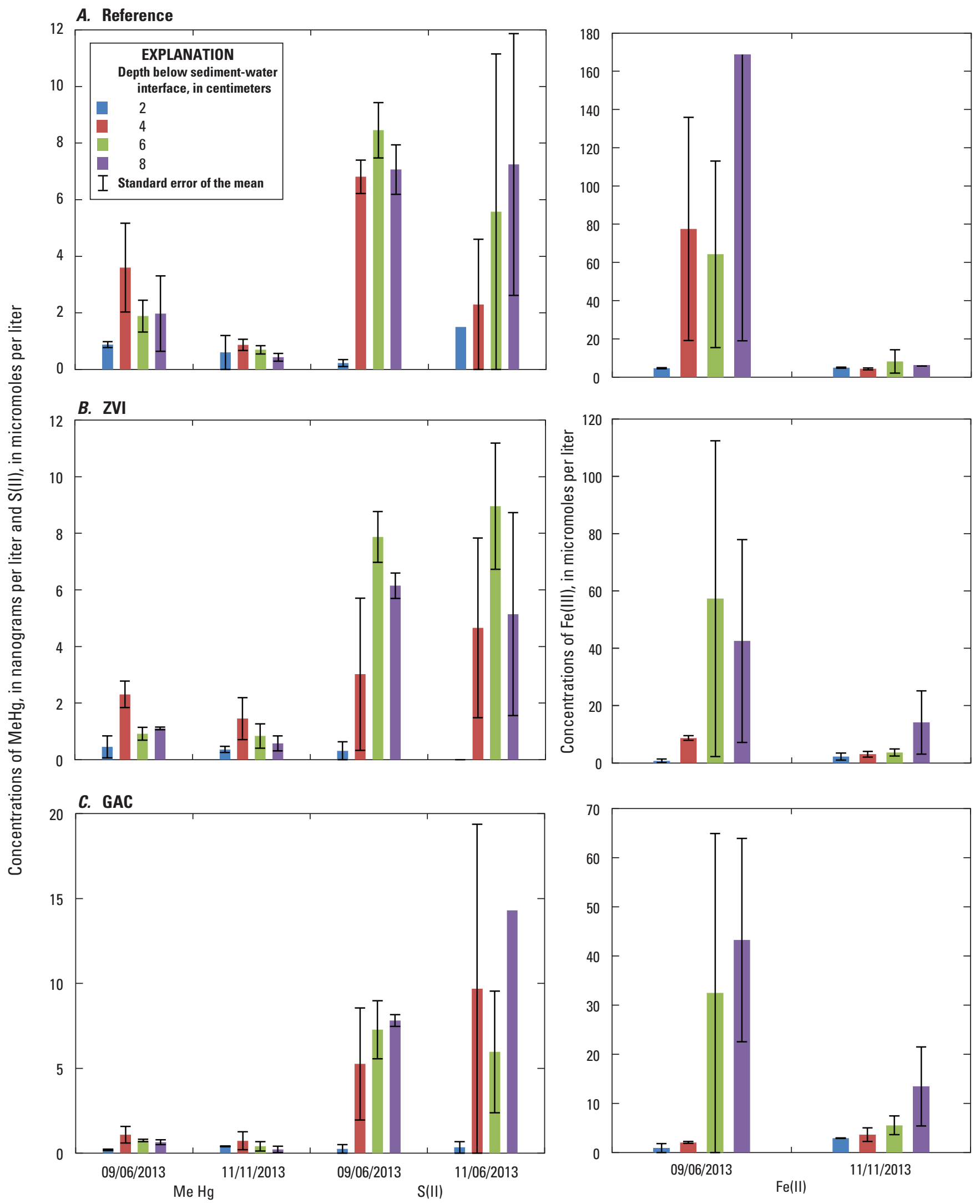

Figure 4. Concentrations of methylmercury (MeHg), sulfide (S(II)), and divalent iron (Fe(II)) in pore water from field mesocosms following $A$, untreated (reference; Experiment 4), and treatments of $B$, zero-valent iron (ZVI) treatment and $C$, granular activated carbon (GAC), sampled at Mount Desert Island, Maine, September 6 and November 11, 2013, at four depths below the sediment-water interface. 


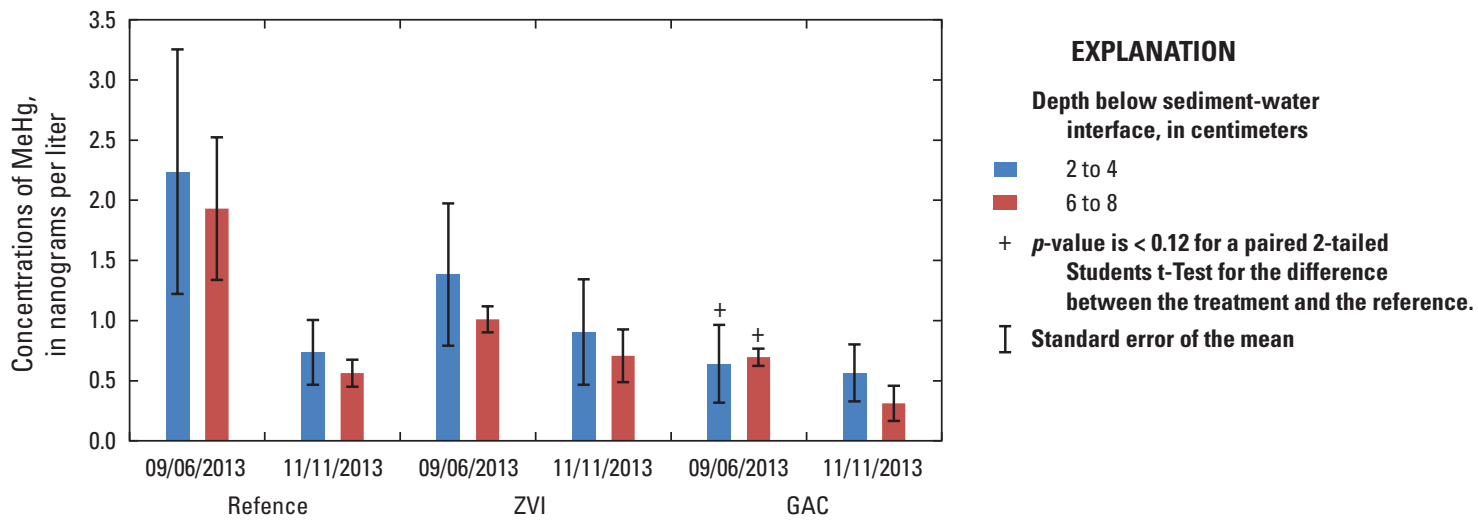

Figure 5. Concentrations of methylmercury (MeHg) in pore water collected from field mesocosms from Mount Desert Island, Maine, on September 6 and November 11, 2013, for Experiment 4. Samples included untreated (reference) and treated zero-valent iron (ZVI) and granular activated carbon (GAC), at 2 to 4 and 6 to $8 \mathrm{~cm}$ depth below the sediment-water interface.

The distribution coefficient for $\mathrm{MeHg}\left(\mathrm{MeHg} \mathrm{K}_{\mathrm{p}}\right)$ increased $(p<0.05)$ in sediment at $6 \mathrm{~cm}$ depth below the sediment water interface from August 12, 2013, to September 6, 2013, following application of GAC (fig. 7). The $\mathrm{K}_{\mathrm{D}}$ decreased in the sediment at the $4 \mathrm{~cm}$ depth $(p<0.1)$ following application of ZVI from August 12 to September 6, 2013 (fig. 7).

\section{Effects of Zero-Valent Iron and Granular Activated Carbon on Sediment Chemistry and Uptake of Mercury in Snails Using Vegetated Littoral Sediment (Experiment 5)}

Analysis of MeHg in snail tissue from snails of the same cohort that were used in this experiment indicated that snails accumulated a substantial amount of $\mathrm{MeHg}$ in reference, ZVItreated, and GAC-treated microcosms. Before the exposure to treatments, the snail tissue contained $1.2 \mathrm{ng} \mathrm{MeHg} / \mathrm{g} \mathrm{dwt}$ $\mathrm{MeHg}$, and after exposure the tissue contained 103, 41.8, and $64.5 \mathrm{ng} \mathrm{MeHg} / \mathrm{g}$ dwt in the reference, ZVI-treated and GACtreated microcosms, respectively. The application of ZVI to vegetated littoral sediment from wetlands fringing Hodgdon Pond maintained in glass aquaria in this second experiment using snails resulted in a significant decrease in $\mathrm{MeHg}$ concentration in snail tissue compared with the reference treatments (table 5). The GAC application appeared to reduce the concentration of $\mathrm{MeHg}$ in snail tissue compared with the reference treatments but the decrease was not statistically significant ( $p=0.17$ ). The application of ZVI did not affect the concentration of $\mathrm{MeHg}$ in the sediment, but the application of GAC increased the concentration of $\mathrm{MeHg}$ in the sediment and lowered the ratio of $\mathrm{MeHg}$ in snail tissue to $\mathrm{MeHg}$ in the sediment (table 5). There were few differences in the Fe fractions in this experiment. The concentration of $\mathrm{Fe}(\mathrm{II})_{\mathrm{AE}}$ was lower in the GAC treatments compared with the reference treatments and ZVI treatments (table 5). The ratio of $\mathrm{Fe}(\mathrm{II})_{\mathrm{AE}}$ to the sum of $\mathrm{Fe}(\mathrm{III}) \mathrm{a}$ and $\mathrm{Fe}(\mathrm{III}) \mathrm{c}$ was lower in the ZVI treatments compared with the reference and GAC treatments.

The concentration of MeHg in surface sediment tended to be lower in the ZVI-treated mesocosms and higher in the GAC-treated mesocosms than in the reference treatments 125 and 154 days following treatment applications (fig. 8) but these differences were not statistically significant $(p<0.05)$. The p-value for the difference between the reference and ZVI-treated mesocosms for 154 days post treatment was 0.17 . The concentration of $\mathrm{MeHg}$ in pore water tended to be lower in the ZVI-treated mesocosms than in the reference treatments 125 and 154 days following treatment applications (fig. 8) but these differences were not statistically significant $(p<0.05)$.

\section{Discussion of Experimental Results}

The laboratory experiments where ZVI was applied to blended littoral and profundal sediment in columns indicated that the concentration of $\mathrm{Fe}$ (II) increased following application of ZVI. The increase in Fe(II) was expected based on the anticipation of two-electron oxidation of elemental $\mathrm{Fe}$ to $\mathrm{Fe}$ (II) and its subsequent one-electron oxidation to poorly crystalline $\mathrm{Fe}(\mathrm{III}) \mathrm{a}$. Following the application of ZVI, $\mathrm{pH}$ increased from about 5.6 to 6.4. The concentration of $\mathrm{MeHg}$ in pore water was at or below detection in these conditions.

At the higher ZVI addition treatment, and in the 2- and 4-cm depths, pore-water DOC concentration appeared to decrease, possibly a result of DOC sorption to solid-phase $\mathrm{Fe}$ (III) surfaces. An increase in $\mathrm{pH}$ would normally be expected to result in an increase in DOC as has been observed 

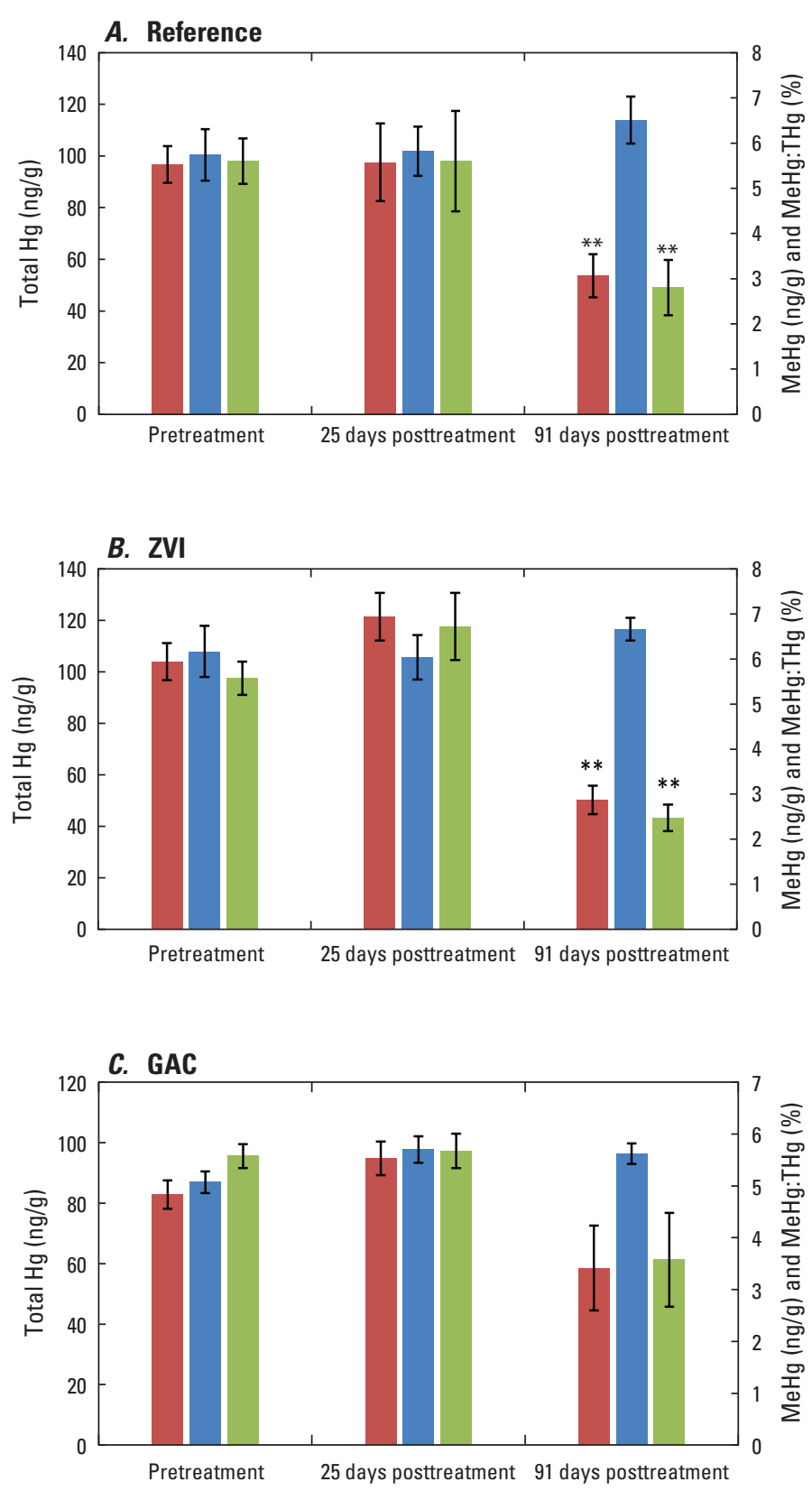

EXPLANATION

- $\mathrm{THg}$

- $\mathrm{MeHg}$

MeHg:THg

I Standard error of the mean

** $\quad p$-value of $<0.01$ for a paired 2-tailed Students $\mathrm{t}$-Test for the difference between

the treatment and the reference

Figure 6. Concentrations of total mercury (THg), methylmercury (MeHg), and $\mathrm{MeHg}: \mathrm{THg}$ for sediment sampled from field mesocosms (Experiment 4) from Mount Desert Island, Maine. Samples were collected at 0 to $3 \mathrm{~cm}$ depth below the sediment-water interface for $A$, untreated (reference), and $B$, treated with zero-valent iron (ZVI), and $C$, treated with granular activated carbon (GAC) at pretreatment and 25 and 91 days posttreatment. $\mathrm{ng} / \mathrm{g}$, nanograms per gram; \%, percent; $\mathrm{THg}$, total mercury; $\mathrm{MeHg}: \mathrm{THg}$, ratio of methylmercury to total mercury. 

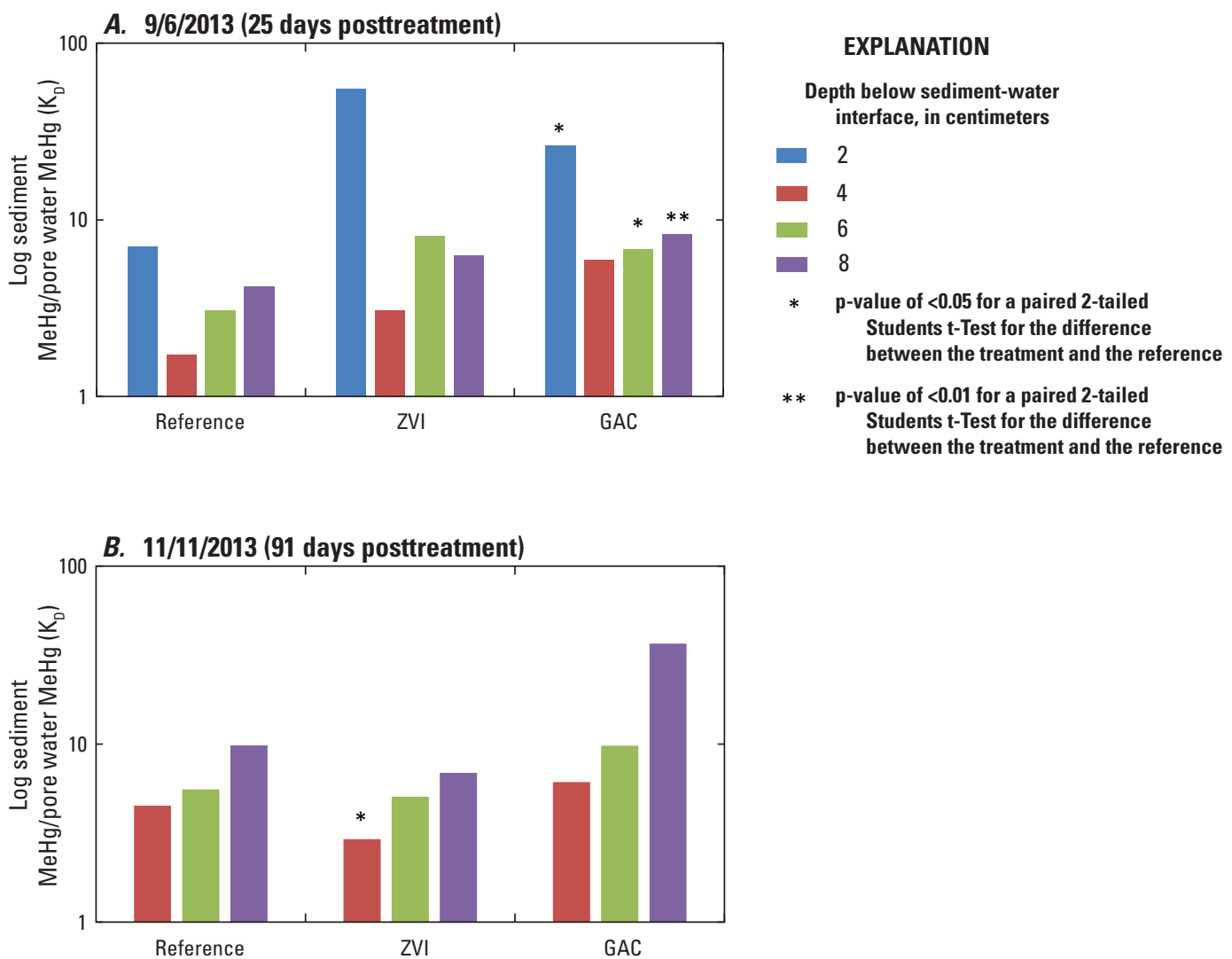

Figure 7. Log of the distribution coefficient $\left(\mathrm{K}_{\mathrm{D}}\right)$ for concentrations of methylmercury $(\mathrm{MeHg})$ between sediment and pore water sampled from field mesocosms (Experiment 4) for $A, 25$ days posttreatment; and $B, 91$ days posttreatment from Mount Desert Island, Maine. Treatments included untreated (reference); $\mathrm{ZVI}$, zero-valent iron; and GAC, granular activated carbon.

in other aquatic systems (Monteith and others, 2007). In these experiments, without vegetation, there were no new root exudates released to the pore water, so pore-water DOC concentrations may have been more affected than they would have been if live vegetation were present. The decrease in DOC observed at the higher rate of ZVI addition (table 2) may have resulted from an increase in DOC sorption to a substantially increased abundance of solid-phase Fe(III) surfaces that have a high affinity for binding DOC.

Results of the analysis of $\mathrm{Fe}$ speciation in Experiment 3 indicate that a substantial fraction of the added ZVI (elemental $\mathrm{Fe}^{0}$ ) was oxidized to $\mathrm{Fe}(\mathrm{II})_{\mathrm{AE}}$ and subsequently to amorphous or poorly crystalline, $\mathrm{Fe}(\mathrm{III}) \mathrm{a}$ and crystalline $\mathrm{Fe}(\mathrm{III}) \mathrm{c}$. This oxidation is reported to be largely abiotic in the presence of sufficient oxygen but can occur in anoxic environments facilitated by sulfur reducing bacteria or methanogenic bacteria (Enning and Garrelfs, 2014; Uchiyama and others, 2010). The Fe(III)a pool is reported to be the primary substrate for microbial reduction of solid-phase Fe(III) to Fe(II) (Roden and Wetzl, 2002). These abiotic oxidation reactions and microbial reduction were anticipated to create conditions that could result in an inhibition of the methylation of mercury as discussed in the section on potential remediation mechanisms. However, the application of ZVI tended to increase the amount of $\mathrm{MeHg}$ associated with surficial sediment in one experiment (Experiment 3); therefore it is possible that for the conditions of Experiment $3 \mathrm{Fe}$ reducing bacteria were stimulated to methylate Hg. Apparently, this stimulation of $\mathrm{MeHg}$ production outweighed any effect of decreasing methylation by sulfate reducing bacteria or reduction of availability of $\mathrm{Hg}(\mathrm{II})$ by sorption to iron oxide surfaces or conversion of $\mathrm{Hg}(\mathrm{II})$ to $\mathrm{Hg}^{0}$ and gaseous evasion. These results from Experiment 3 contrasted with those of Experiment 5 where ZVI did not increase the amount of MeHg associated with the sediment and tended to decrease it, though the differences were not statistically significant.

There were no significant differences in $\mathrm{MeHg}$ uptake in snails in Experiment 3, comparing the effects of ZVI additions to reference treatments. However, in Experiment 5 in similar conditions to those in Experiment 3, ZVI treatments 


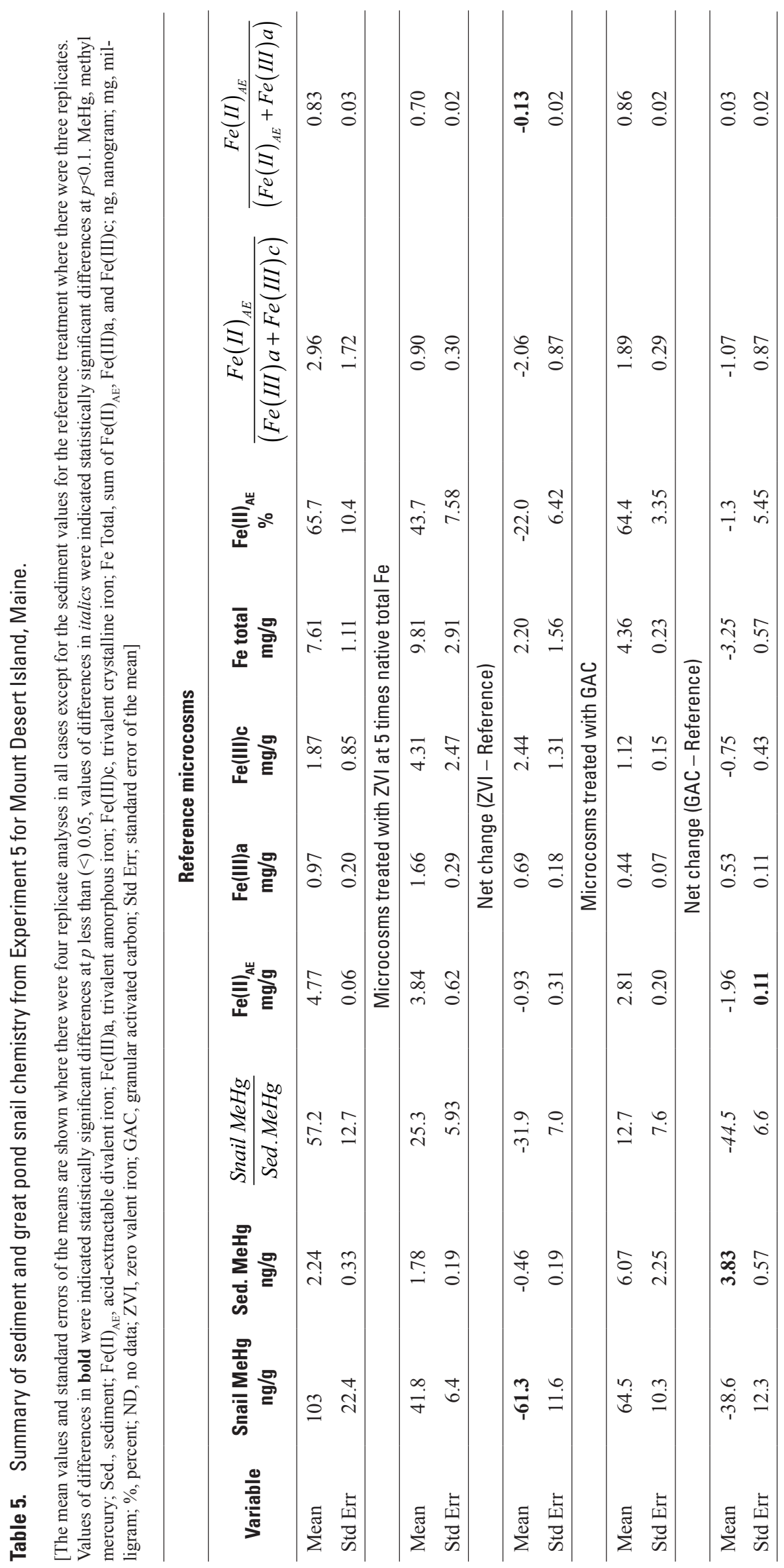




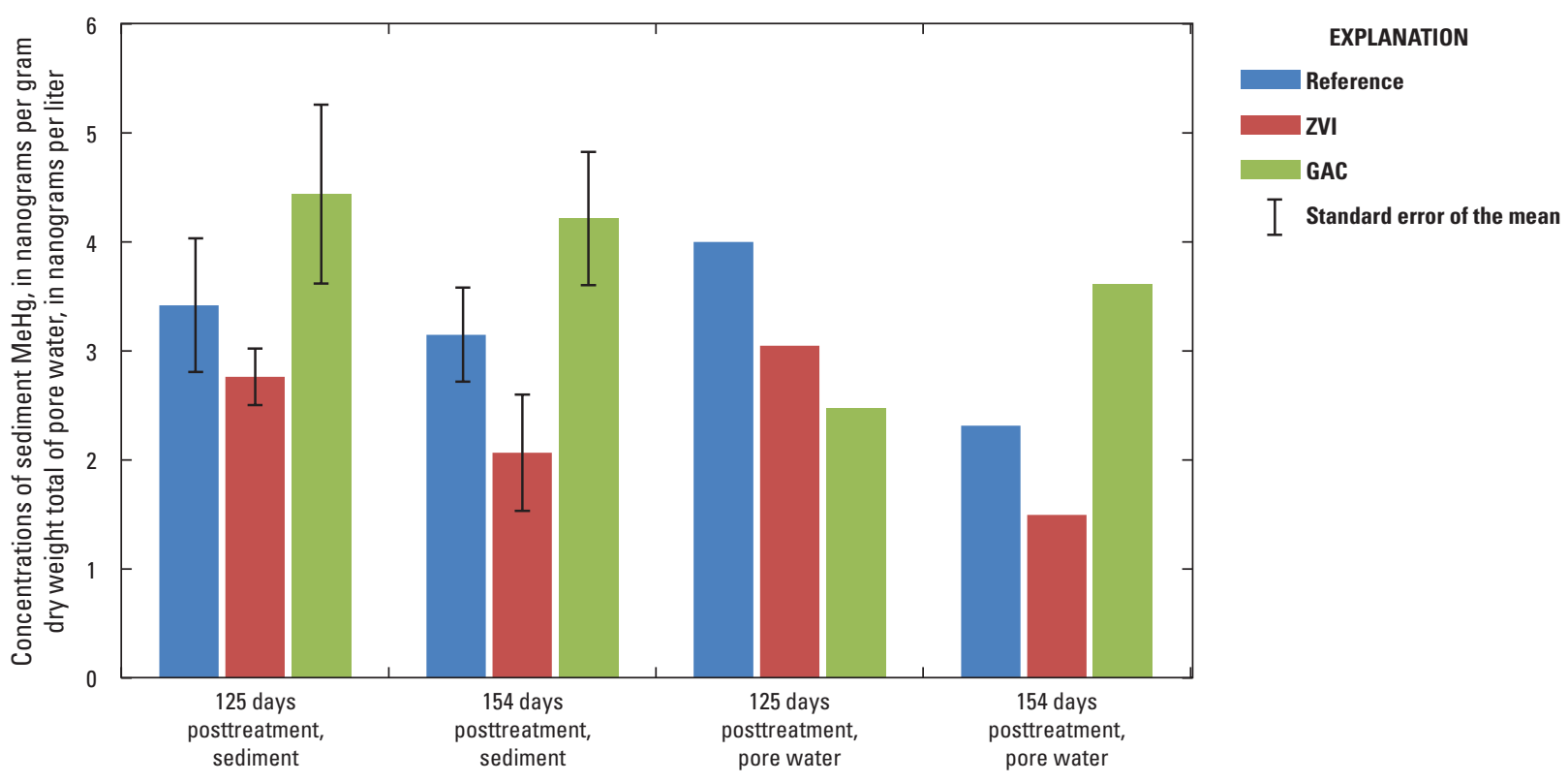

Figure 8. A comparison of concentrations of methylmercury $(\mathrm{MeHg}$ ) in sediment (four samples) and pore water (two samples) sampled 125 and 154 days posttreatment of zero-valent iron (ZVI) and granular activated carbon (GAC) in laboratory mesocosms containing vegetated sediment to untreated (reference) samples, Experiment 5, for Mount Desert Island, Maine. ng/g dwt, nanograms per gram dry weight; ng/L, nanograms per liter.

resulted in significantly less uptake of MeHg in snail tissue than observed in reference treatments. In Experiment 5, the application of GAC did not significantly reduce the uptake of $\mathrm{MeHg}$ in snail tissue in comparison with the reference treatments. We cannot explain the fact that ZVI did not reduce $\mathrm{MeHg}$ uptake in Experiment 3 but did in Experiment 5 . The vegetated clumps of sediment were collected on September 10, 2012, for Experiment 3 and on October 14, 2013, for Experiment 5. In Experiment 5, there was less total sediment mass and substantially more overlying water in the microcosms, which may have affected the redox regime and therefore methylation. Both experiments were carried out in the laboratory under similar light and temperature regimes. The snails tended to remain on the surface of the sediment, on the vegetation, or on the walls of the aquaria near the sediment water interface. Because the snails did not seem to ingest live vegetation, it is assumed that during the exposure they subsisted on a diet of periphyton and detritus. In both experiments there were similar amounts of vegetation, and presumably live roots, but the actual amounts were not quantified. Both experiments had similar periods of ZVI equilibration with surface sediment before adding snails; 121 days for Experiment 3 and 112 days for Experiment 5 . One difference between experiments was that in Experiment 3 the snail exposure period was shorter (28 days) compared to the exposure period in Experiment 5 (41 days). It is possible that the snails ingested substantially more detritus and periphyton in Experiment 5 than in Experiment 3, especially so if the snails initially avoided the lower quality food in the mesocosms compared with their diet of romaine lettuce before the exposure in the aquaria.

The results of the field mesocosm experiment (Experiment 4) indicated that there was a decreasing trend in pore-water $\mathrm{MeHg}$ concentration after application of GAC, but because there was no corresponding decrease in sediment $\mathrm{MeHg}$ concentration, mercury methylation was apparently not affected. Rather, the data indicate that the application of GAC resulted in the sorption of $\mathrm{MeHg}$ to GAC thereby increasing the partitioning of $\mathrm{MeHg}$ to GAC and decreasing $\mathrm{MeHg}$ concentration in pore water but not inhibiting mercury methylation rate. Sorption of $\mathrm{MeHg}$ by GAC has been reported in contaminated freshwater and estuarine sediment with organic matter contents similar to those in this study (Gilmour and others, 2013).

The seasonal decrease in $\mathrm{MeHg}$ concentration in sediment from summer to fall in the field mesocosm (Experiment 4) is consistent with reports from other temperate wetlands and estuarine sediment (Heim and others, 2007; Mitchell and Gilmour, 2008; Selvendiran and others, 2008; Bradley and others, 2011; Bergman and others, 2012). This pattern of seasonal decrease in sediment $\mathrm{MeHg}$ has been attributed to higher activity of sulfate and iron reducing bacteria in spring and summer than in fall and winter. Lower microbial activity in the fall is consistent with our observations that DOC 
concentrations were substantially lower in the fall compared with in the summer (data not shown). Seasonal variability in the activity of the macrophytes in these field mesocosms also may have played a role in the observed pattern of $\mathrm{MeHg}$ concentration in sediment. Macrophytes can affect rhizosphere processes by affecting $\mathrm{pH}$, redox potential $\left(\mathrm{E}_{\mathrm{h}}\right)$ and by the exudation of organic ligands (Cosio and others, 2014) and these effects would be more pronounced during periods of active growth in the summer than when plants were senescing in the fall. Microbial activity also may be decreased in the fall as temperatures decline and plants senesce and there is less labile dissolved organic matter.

The fact that ZVI did not lower MeHg concentrations in pore water compared with the reference treatments could be explained by ZVI having a stimulating effect on iron reducing bacteria that methylated $\mathrm{Hg}$. Results from the laboratory mesocosm Experiment 5 indicated that in that application of ZVI concentrations of $\mathrm{MeHg}$ in pore water tended to be lower than those measured in the reference treatments. Because $\mathrm{MeHg}$ concentrations in sediment were also lower in the ZVI treatments of Experiment 5 it suggests that the ZVI may have reduced methylation rather than acted solely as a sorbent in that case. In Experiment 5 the MeHg concentrations in pore water were lower in GAC-treated plots compared to reference plots after 125 days, consistent with GAC acting as a sorbent, but after 154 days $\mathrm{MeHg}$ concentrations were higher.

The observed increase in $\mathrm{K}_{\mathrm{D}}$ for $\mathrm{MeHg}$ following the application of GAC also indicates that the addition of GAC shifted the equilibrium from the dissolved phase towards the sorbed phase. The application of ZVI did not increase the $\mathrm{K}_{\mathrm{D}}$ for $\mathrm{MeHg}$ and in one case, at the $4 \mathrm{~cm}$ sampling depth, decreased it, which would be consistent with ZVI increasing mercury methylation more than sorption in that experiment.

\section{Limitations of This Study and Potential for Future Research}

This study was designed to evaluate the potential for the amendments ZVI and GAC to decrease mercury methylation, pore-water and sediment $\mathrm{MeHg}$ concentrations and biological uptake of $\mathrm{Hg}$ and $\mathrm{MeHg}$. The study was not designed to determine the mechanisms that would explain decreases in methylation, $\mathrm{MeHg}$ concentrations or uptake. Further research with additional measurements could improve understanding of the mechanisms behind decreases in pore-water $\mathrm{MeHg}$ concentrations. For example, monitoring of redox conditions using probes to measure oxidation reduction potential as the season progressed and water levels and plant activity varied during the course of the summer and fall would be particularly helpful in understanding the fate of mercury in these systems. Similarly more frequent sampling for monitoring mercury and iron species, sulfide, and DOC would support a more mechanistic understanding. The field experiment began in mid-August with an unusually dry period during which total precipitation between August 12 and November 11 was $19.6 \mathrm{~cm}$ compared with the average for that period from 1982 to 2013, which was $41.9 \mathrm{~cm}$ (standard deviation, $13.3 \mathrm{~cm}$; National Atmospheric Deposition Program, undated). It would be very useful to monitor $\mathrm{MeHg}$ in a more typical year where precipitation was higher and where the water level in Hodgdon Pond did not vary as much as it did in 2013.

The length of the experimental period is of potential concern because ideally it should be long enough to observe a response in the variables of interest and to evaluate the persistence of the effect of the chemical addition. Our experiments involving 1 to 3 months of exposure were long enough to observe responses in sediment, pore-water, and snail tissue chemistry. Results from other studies on the biouptake of trace metals in the great pond snail L. stagnalis (Croteau and Luoma, 2009; Croteau and others, 2011), mercury in L. stagnalis (Tessier and others, 2007) or mercury in the oligochaete Lumbriculus variegatus (Gilmour and others, 2013) have indicated that relatively short term experiments of hours to weeks are sufficient to determine if the uptake of toxic metals is affected by the conditions of the experiment. However, 1 to 3 month periods were not sufficient to evaluate if the effects observed would be observed for longer periods. Studies in which pore-water and sediment chemistry are monitored for several years following additions would inform resource managers of the potential persistence of these effects. Longer term monitoring also would be helpful to track effects on sediment $\mathrm{pH}$, phosphorus availability, and potential effects on algal growth. The short term laboratory column experiments were carried out in conditions of little variation in temperature or water level and therefore may not be representative of actual field conditions. The laboratory experiments with unvegetated microcosms obviously lacked the rhizosphere environments where live macrophytes affect microbial activity and pore-water and sediment geochemistry and redox conditions (Cosio and others, 2014).

Future experiments could include microbial assays and the use of specific inhibitors to reveal existing populations and activity of sulfur and iron reducing bacteria. These kinds of experiments could help to identify bacteria responsible for methylation of mercury in this sediment and how they were affected by additions of ZVI and GAC. More frequent sampling of MeHg in pore water and sediment would help in understanding variations in rates of methylation or demethylation in different experimental conditions. It also could be helpful to monitor the uptake of mercury and $\mathrm{MeHg}$ in periphyton and macrophytes over the course of a summer and fall season.

\section{Summary}

The U.S. Geological Survey in cooperation with Acadia National Park, carried out a series of laboratory and field experiments to evaluate the potential of zero-valent iron and granular activated carbon to reduce the rate of the bacterially 
mediated process of mercury methylation and subsequent biological uptake in the great pond snail Lymnaea stagnalis. It was apparent that the addition of zero-valent iron resulted in an increase in divalent iron and especially poorly crystalline amorphous trivalent iron. Our original hypothesis that these reactions would reduce methylation by binding the substrates for bacterial methylation was not consistently supported. In our initial column experiments without vegetation, the application of zero-valent iron tended to increase the amount of methylmercury associated with surficial sediment; therefore, it is more likely that iron reducing bacteria were stimulated to methylate mercury. Apparently, this stimulation of methylmercury production outweighed any effect of decreasing methylation by decreasing concentrations of the substrates sulfide or divalent mercury through chemical binding to iron, sorption to amorphous trivalent iron surfaces or evasion of mercury.

The results of the field mesocosm experiments indicated that application of granular activated carbon decreased pore-water methylmercury concentration, but there was no corresponding decrease in sediment methylmercury concentration; hence, the sediment-pore water distribution coefficient or methylmercury increased. These results indicated that mercury methylation was not affected by the addition of granular activated carbon. Rather, the data indicate that the application of granular activated carbon resulted in the sorption of methylmercury to granular activated carbon thereby decreasing methylmercury concentration in pore water but not inhibiting the mercury methylation rate. The application of zero-valent iron did not increase the sedimentpore water distribution coefficient for methylmercury.

The results of our two experiments to test the effect of zero-valent iron on the uptake of methylmercury in snails in laboratory mesocosms were mixed. The fact that the great pond snail $L$. stagnalis accumulated a substantial amount of methylmercury in relatively short exposure periods (41 days or less) in laboratory mesocosm experiments with intact vegetated sediment indicates that these snails are useful for evaluating the potential of zero-valent iron and granular activated carbon as amendments to reduce biouptake of methylmercury in this wetland sediment.

Although zero-valent iron addition did not consistently result in a decrease in the methylation of divalent mercury in the Hodgdon Pond sediment based on the analysis of methylmercury in sediment, it is possible that it would be effective in estuarine sediment where sulfide concentrations were higher than in the Hodgdon Pond freshwater sediment. Further research could evaluate the potential for zero-valent iron to inhibit methylation in estuarine sediment. The results reported here indicate that, in certain conditions, zero-valent iron and granular activated carbon may have potential as sorbents to reduce the biomagnification of methylmercury in freshwater wetland sediment at Acadia National Park. The experiments with zero-valent iron indicated that in certain conditions zerovalent iron may inhibit the methylation of mercury and the biouptake of methylmercury but the results were inconclusive because of differences between experiments. Further research could be helpful in understanding the conditions under which zero-valent iron can be effective at decreasing mercury methylation and the biouptake of methylmercury. Additional research also is needed to evaluate the potential detrimental effects of zero-valent iron and granular activated carbon on biota in this sediment.

\section{References Cited}

Acadia National Park, 2010, Mercury contamination at Acadia National Park: National Park Service issue brief, June, 2 p., accessed September 30, 2014, at http://www.nps.gov/acad/ naturescience/upload/ACAD_Mercury_FactSheet_2010. pdf.

Amirbahman, Aria, Kent, D.B., Curtis, G.P., and MarvinDipasquale, M.C., 2013, Kinetics of homogeneous and surface-catalyzed mercury(II) reduction by iron(II): Environmental Science and Technology, v. 47, no. 13, p. 7204-7213.

Amirbahman, Aria, Ruck, P.L., Fernandez, I.J., Haines, T.A., and Kahl, J.S., 2004, The effect of fire on mercury cycling in the soils of forested watersheds-Acadia National Park, Maine, USA: Water, Air, and Soil Pollution, v. 152, nos. 1-4, p. 315-331.

Bacon, Linda, 2013, Maine lakes transparency, color \& chemistry-Overall mean values: Maine Department of Environmental Protection and Maine Volunteer Lake Monitoring Program dataset, accessed March 29, 2014, at http://www.gulfofmaine.org $/ \mathrm{kb} / 2.0 /$ record.html? recordid $=9678$.

Bank, M.S., Burgess, J.R., Evers, D.C., and Loftin, C.S., 2007a, Mercury contamination of biota from Acadia National Park, Maine-A review: Environmental Monitoring and Assessment, v. 126, no. 1-3, p. 105-115.

Bank, M.S., Crocker, Jeff, Connery, Bruce, and Amirbahman, Aria, 2007b, Mercury bioaccumulation in green frog (Rana clamitans) and bullfrog (Rana catesbeiana) tadpoles from Acadia National Park, Maine, USA: Environmental Toxicology and Chemistry, v. 26, no. 1, p. 118-125.

Bank, M.S., Loftin, C.S., and Jung, R.E., 2005, Mercury bioaccumulation in northern two-lined salamanders from streams in the northeastern United States: Ecotoxicology, v. 14 , nos. $1-2$, p. 181-191.

Benoit, J.M., Cato, D.A., Denison, K.C., and Moreira, A.E., 2013, Seasonal mercury dynamics in a New England vernal pool: Wetlands, v. 33, no. 5, p. 887-894. 
Benoit, J.M., Gilmour, C.C., Heyes, A., Mason, R.P., and Miller, C.L., 2003, Geochemical and biological controls over methylmercury production and degradation in aquatic ecosystems, chap. 19 of Cai, Yong, and Braids, O.C., eds., Biogeochemistry of environmentally important trace elements: Washington, D.C., American Chemical Society Symposium Series, v. 835, p. 262-297.

Benoit, J.M., Gilmour, C.C., and Mason, R.P., 2001, Aspects of bioavailability of mercury for methylation in pure cultures of Desulfobulbus propionicus (1pr3): Applied and Environmental Microbiology, v. 67, no. 1, p. 51-58.

Benoit, J.M., Mason, R.P., and Gilmour, C.C., 1999, Estimation of mercury-sulfide speciation in sediment pore waters using octanol-water partitioning and implications for the availability to methylating bacteria: Environmental Toxicology and Chemistry, v. 18, no. 10, p. 2138-2141.

Bergman, Inger, Bishop, Kevin, Tu, Qiang, Frech, Wolfgang, Åkerblom, Staffan, and Nilsson, Mats, 2012, The influence of sulphate deposition on the seasonal variation of peat pore water methyl $\mathrm{Hg}$ in a boreal mire: PLoS ONE, v. 7, no. 9, paper e45547, $10 \mathrm{p}$., accessed July 25, 2014, at http://dx.doi.org/10.1371/journal.pone.0045547.

Boesch, D.F., Burroughs, R.H., Baker, J.E., Mason, R.P., Rowe, C.L., and Siefert, R.L., 2001, Marine pollution in the United States: Arlington, Virginia, The Pew Charitable Trusts, 50 p., accessed April 28, 2013, at http://www.pewtrusts.org/en/research-and-analysis/ reports/2001/02/12/marine-pollution-in-the-united-states.

Bradley, P.M., Burns, D.A., Murray, K.R., Brigham, M.E., Button, D.T., Chasar, L.C., Marvin-DiPasquale, Mark, Lowery, M.A., and Journey, C.A., 2011, Spatial and seasonal variability of dissolved methylmercury in two stream basins in the eastern United States: Environmental Science and Technology, v. 45, no. 6, p. 2048-2055.

Carignan, Richard, St-Pierre, Sylvie, and Gachter, Rene, 1994, Use of diffusion samplers in oligotrophic lake sedimentsEffects of free oxygen in sampler material: Limnology and Oceanography, v. 39 , no. 2, p. 468-474.

Charlet, Laurent, Bosbach, Dirk, and Peretyashko, Tanya, 2002, Natural attenuation of TCE, As, Hg linked to the heterogeneous oxidation of $\mathrm{Fe}(\mathrm{II})$ - An AFM study: Chemical Geology, v. 190, nos. 1-4, p. 303-319.

Cline, J.D., 1969, Spectrophotometric determination of hydrogen sulfide in natural waters: Limnology and Oceanography, v. 14 , no. 3 , p. $454-458$.

Compeau, G.C., and Bartha, Richard, 1985, Sulfate-reducing bacteria-Principal methylators of mercury in anoxic estuarine sediment: Applied and Environmental Microbiology, v. 50 , no. 2 , p. $498-502$.
Cosio, Claudia, Fluck, Rebecca, Regier, Nicole, and Slaveykova, V.I., 2014, Effects of macrophytes on the fate of mercury in aquatic systems: Environmental Toxicology and Chemistry, v. 33, no. 6, p. 1225-1237.

Croteau, M.-N., Dybowska, A.D., Luoma, S.N., and ValsamiJones, Eugenia, 2011, A novel approach reveals that zinc oxide nanoparticles are bioavailable and toxic after dietary exposures: Nanotoxicology, v. 5, no. 1, p. 79-90.

Croteau, M.-N., and Luoma, S.N., 2009, Predicting dietborne metal toxicity from metal influxes: Environmental Science and Technology, v. 43, no. 13, p. 4915-4921.

Dennis, I.F., Clair, T.A., Driscoll, C.T., Kamman, Neil, Chalmers, Ann, Shanley, Jamie, Norton, S.A., and Kahl, Steve, 2005, Distribution patterns of mercury in lakes and rivers of northeastern North America: Ecotoxicology, v. 14, nos. 1-2, p. 113-123.

Desrosiers, Mélanie, Planas, Dolors, and Mucci, Alfonso, 2006, Mercury methylation in the epilithon of Boreal Shield aquatic ecosystems: Environmental Science \& Technology, v. 40 , p. $1540-1546$.

DeWild, J.F., Olson, M.L., and Olund, S.D., 2001, Determination of methylmercury by aqueous phase ethylation, followed by gas chromatographic separation with cold vapor atomic fluorescence detection: U.S. Geological Survey Open-File Report 01-445, 14 p. [Also available at http://pubs.usgs.gov/of/2001/ofr-01-445/.]

Driscoll, C.T., Han, Y.J., Chen, C.Y., Evers, D.C., Lambert, K.F., Holsen, T.M., Kamman, N.C., and Munson, R.K., 2007, Mercury contamination in forest and freshwater ecosystems in the northeastern United States: Bioscience, v. 57, no. 1, p. 17-28.

Eisler, Ronald, 2006, Mercury hazards to living organisms: Boca Raton, Fla., CRC Press, 336 p.

Enning, Dennis, and Garrelfs, Julia, 2013, Corrosion of iron by sulfate-reducing bacteria-New views of an old problem: Applied and Environmental Microbiology, v. 80, no. 4, p. 1226-1236.

Farag, A.M., Woodward, D.F., Goldstein, J.N., Brumbaugh, William, and Meyer, J.S., 1998, Concentrations of metals associated with mining waste in sediments, biofilm, benthic macroinvertebrates, and fish from the Coeur d'Alene River basin, Idaho: Archives of Environmental Contamination and Toxicology, v. 134, p. 119-127.

Fleming, E.J., Mack, E.E., Green, P.G., and Nelson, D.C., 2006, Mercury methylation from unexpected sourcesMolybdate-inhibited freshwater sediments and an iron-reducing bacterium: Applied and Environmental Microbiology, v. 72, no. 1, p. 457-464. 
Florida Department of Environmental Protection, 2011, Analysis of methylmercury in sediment and tissue by $\mathrm{KOH} /$ $\mathrm{CH}_{3} \mathrm{OH}$ digestion followed by aqueous phase ethylation: Florida Department of Environmental Protection HG-0032.12, 24 p. [Also available at ftp://ftp.dep.state.fl.us/pub/ labs/lds/sops/6388.pdf.]

Fossing, Henrik, and Jørgensen, B.B., 1989, Measurement of bacterial sulfate reduction in sediments - Evaluation of a single step chromium reduction method: Biogeochemistry, v. 8 , no. 3, p. 205-222.

Gerbig, C.A., Kim, C.S., Stegemeier, J.P., Ryan, J.N., and Aiken, G.R., 2011, Formation of nanocolloidal metacinnabar in mercury-DOM-sulfide systems: Environmental Science and Technology, v. 45, no. 21, p. 9180-9187.

Ghosh, Upal, Luthy, R.G., Cornelissen, Gerard, Werner, David, and Menzie, C.A., 2011, In-situ sorbent amendments - A new direction in contaminated sediment management: Environmental Science and Technology, v. 45, no. 4, p. 1163-1168.

Ghosh, Upal, Reed, B.E., Kwon, Seokjoon, Thomas, Jeff, Bridges, Todd, Farrar, Daniel, Magar, Victor, and Levine, Laura, 2008, Rational selection of tailored amendment mixtures and composites for in situ remediation of contaminated sediments - Final report: Alexandria, Va., Strategic Environmental Research and Development Program, Project ER-1491, 53 p. plus appendixes.

Gilmour, C.C., and Henry, E.A., 1991, Mercury methylation in aquatic systems affected by acid deposition: Environmental Pollution, v. 71, no. 2-4, p. 131-169.

Gilmour, C.C., Henry, E.A., and Mitchell, Ralph, 1992, Sulfate stimulation of mercury methylation in freshwater sediments: Environmental Science and Technology, v. 26, no. 11, p. 2281-2287.

Gilmour, C.C., Riedel, G.S., Riedel, Gerhardt, Kwon, Seeokjoon, Landis, Richard, Brown, S.S., Menzie, C.A., and Ghosh, Upal, 2013, Activated carbon mitigates mercury and methylmercury bioavailability in contaminated sediments: Environmental Science and Technology, v. 47, no. 22, p. 13001-13010.

Gomez-Eyles, J.L., Yupanqui, Carmen, Beckingham, Barabara, Riedel, Gerhardt, Gilmour, C.C., and Ghosh, Upal, 2013, Evaluation of biochars and activated carbons for in situ remediation of sediments impacted with organics, mercury, and methylmercury: Environmental Science and Technology, v. 47, no. 23, p. 13721-13729.

Hamelin, Stéphanie, Amyot, Marc, Barkay, Tamar, Wang, Yanping, and Planas, Dolors, 2011, MethanogensPrincipal methylators of mercury in Lake Periphyton: Environmental Science and Technology, v. 45, no. 18, p. 7693-7700.
Han, Seunghee, Obraztsova, Anna, Pretto, Patrizia, Choe, K.Y., Gieskes, Joris, Deheyn, D.D., and Tebo, B.M., 2007, Biogeochemical factors affecting mercury methylation in sediments of the Venice Lagoon, Italy: Environmental Toxicology and Chemistry, v. 26, no. 4, p. 655-663.

Heim, W.A., Coale, K.H., Stephenson, Mark, Choe, K.-Y., Gill, G.A., and Foe, Chris, 2007, Spatial and habitat-based variations in total and methylmercury concentrations in surficial sediments in the San Francisco Bay-Delta: Environmental Science and Technology, v. 41, no. 10, p. 3501-3507.

Kerin, E.J., Gilmour, C.C., Roden, E., Suzuki, M.T., Coates, J.D., and Mason, R.P., 2006, Mercury methylation by dissimilatory iron-reducing bacteria: Applied and Environmental Microbiology, v. 72, p. 7919-7921.

Koretsky, C.M., Haas, J.R., Miller, Douglas, and Ndenga, N.T., 2006, Seasonal variations in pore water and sediment geochemistry of littoral lake sediments (Asylum Lake, Mich., USA): Geochemical Transactions, v. 7, p. 1-26.

Liu, Jianrong, Valsaraj, K.T., and Delaune, R.D., 2009, Inhibition of mercury methylation by iron sulfides in an anoxic sediment: Environmental Engineering Science, v. 26, no. 4, p. 833-840.

Loftin, C.S., Calhoun, A.J.K., Nelson, S.J., Elskus, A.A., and Simon, Kevin, 2012, Mercury bioaccumulation in wood frogs developing in seasonal pools: Northeastern Naturalist, v. 19 , no. 4 , p. 579-600.

Longcore, J.R., Haines, T.A., and Halteman, W.A., 2007, Mercury in tree swallow food, eggs, bodies, and feathers at Acadia National Park, Maine, and an EPA superfund site, Ayer, Massachusetts: Environmental Monitoring and Assessment, v. 126, no. 1-3, p. 129-143.

Maine.gov, [2001], Hodgdon Pond, Tremont Twp., Hancock Co., U.S.G.S. Bartlett Island, ME (7 1/2'): Maine.gov Fishing in Maine Web site, accessed March 29, 2014, at https://www.maine.gov/ifw/fishing/lakesurvey_maps/ hancock/hodgdon_pond.pdf.

Marvin-DiPasquale, Mark, Agee, Jennifer, McGowan, Chad, Oremland, R.S., Thomas, Martha, Krabbenhoft, David, and Gilmour, C.C., 2000, Methylmercury degradation pathways-A comparison among three mercury-impacted ecosystems: Environmental Science and Technology, v. 34, p. $4908-4917$.

Marvin-DiPasquale, Mark, Alpers, C.N., and Fleck, J.A., 2009a, Mercury, methylmercury, and other constituents in sediment and water from seasonal and permanent wetlands in the Cache Creek settling basin and Yolo Bypass, Yolo County, California, 2005-06: U.S. Geological Survey Open-File Report 2009-1182, 69 p. 
Marvin-DiPasquale, Mark, and Cox, M.H., 2007, Legacy mercury in Alviso Slough, South San Francisco Bay, California-Concentration, speciation and mobility: U.S. Geological Survey Open-File Report 2007-1240, 98 p. [Also available at http://pubs.usgs.gov/of/2007/1240/.]

Marvin-DiPasquale, Mark, Lutz, M.A., Brigham, M.E., Krabbenhoft, D.P., Aiken, G.R., Orem, W.H., and Hall, B.D., 2009b, Mercury cycling in stream ecosystems-2. Benthic methylmercury production and bed sediment-pore water partitioning: Environmental Science and Technology, v. 43 , no. 8 , p. $2726-2732$.

Marvin-DiPasquale, Mark, Windham-Myers, Lisamarie, Agee, J.L., Kakouros, Evangelos, Kieu, L.H., Fleck, Jacob, Alpers, C.N., and Stricker, C.A., 2014, Methylmercury production in sediment from agricultural and non-agricultural wetlands in the Yolo Bypass, California: Science of the Total Environment, v. 484, p. 288-299.

Mason, Robert, Bloom, Nicolas, Cappellino, Steve, Gill, Gary, Benoit, Janina, and Dobbs, Charles, 1998, Investigation of porewater sampling methods for mercury and methylmercury: Environmental Science and Technology, v. 32, no. 24, p. 4031-4040.

Mehrotra, A.S., Horne, A.J., and Sedlak, D.L., 2003, Reduction of net mercury methylation by iron in Desulfobulbus propionicus (1pr3) cultures-Implications for engineered wetlands: Environmental Science and Technology, v. 37, no. 13, p. 3018-3023.

Mehrotra, A.S., and Sedlak, D.L., 2005, Decrease in net mercury methylation rates following iron amendment to anoxic wetland sediment slurries: Environmental Science and Technology, v. 39, no. 8, p. 2564-2570.

Mitchell, C.P.J., and Gilmour, C.C., 2008, Methylmercury production in a Chesapeake Bay salt marsh: Journal of Geophysical Research—Biogeosciences, v. 113, no. G2, paper G00C04, 14 p.

Monteith, D.T., Stoddard, J.L., Evans, C.D., de Wit, H.A., Forsius, Martin, Høgåsen, Tore, Wilander, Anders, Skjelkvåle, B.L., Jeffries, D.S., Vuorenmaa, Jussi, Keller, Bill, Kopácek, Jiri, and Vesely, Josef, 2007, Dissolved organic carbon trends resulting from changes in atmospheric deposition chemistry: Nature, v. 450, p. 537-540.

National Atmospheric Deposition Program, [undated], Daily precipitation data for Acadia National Park, Mount Desert Island, Maine: National Atmospheric Deposition Program database, accessed July 29, 2014, at http://nadp.sws.uiuc.edu/data/ntn/.
Nielsen, M.G., 2006, Hydrogeomorphic classification of wetlands on Mt. Desert Island, Maine, including hydrologic susceptibility factors for wetlands in Acadia National Park: U.S. Geological Survey Scientific Investigations Report 2006-5162, 72 p. [Also available at http://pubs.usgs.gov/ $\operatorname{sir} / 2006 / 5162 /$.

Norton, S.A., Evans, G.C., and Kahl, J.S., 1997, Comparison of $\mathrm{Hg}$ and $\mathrm{Pb}$ fluxes to hummocks and hollows of ombrotrophic Big Heath bog and to nearby Sargent Mt. Pond, Maine, USA: Water, Air, and Soil Pollution, v. 100, nos. 3-4, p. 271-286.

Olund, S.D., DeWild, J.F., Olson, M.L., and Tate, M.T., 2004, Methods for the preparation and analysis of solids and suspended solids for total mercury: U.S. Geological Survey Techniques and Methods, book 5, chap. A8, 15 p.

[Also available at http://pubs.usgs.gov/tm/2005/tm5A8/.]

Oremland, R.S., Culbertson, C.W., and Winfrey, M.R., 1991, Methylmercury decomposition in sediments and bacterial cultures-Involvement of methanogens and sulfate reducers in oxidative demethylation: Applied and Environmental Microbiology, v. 57, no. 1, p. 130-137.

Peretyazhko, T., Charlet, L., and Grimaldi, M., 2006, Production of gaseous mercury in topical hydromorphic soils in the presence of ferrous iron-A laboratory study: European Journal of Soil Science, v. 57, no. 2, p. 190-199.

Perry, Ethan, Norton, S.A., Kamman, N.C., Lorey, P.M., and Driscoll, C.T., 2005, Deconstruction of historic mercury accumulation in lake sediments, northeastern United States: Ecotoxicology, v. 14, no. 1-2, p. 85-99.

Prestbo, E.M., and Gay, D.A., 2009, Wet deposition of mercury in the U.S. and Canada, 1996-2005-Results and analysis of the NADP mercury deposition network (MDN): Atmospheric Environment, v. 43, no. 27, p. 4223-4233.

Roden, E.E., and Wetzel, R.G., 2002, Kinetics of microbial $\mathrm{Fe}(\mathrm{III})$ oxide reduction in freshwater wetland sediments: Limnology and Oceanography, v. 47, no. 1, p. 198-211.

Ruck, P.L., 2002, Cycling and speciation of mercury in soils at Cadillac Brook and Hadlock Brook Watersheds, Acadia National Park: Orono, Maine, University of Maine, Master's thesis,. 114 p. [Also available at http://www.library.umaine.edu/theses/pdf/ RuckPL2002.pdf.]

Schaefer, J.K., and Morel, F.M.M., 2009, High methylation rates of mercury bound to cysteine by Geobacter sulfurreducens: Nature Geosciences, v. 2, no. 2, p. 123-126. 
Schaefer, J.K., Rocks, S.S., Zheng, Wang, Liang, Liyuan, Gu, Baohua, and Morel, F.M.M., 2011, Active transport, substrate specificity, and methylation of $\mathrm{Hg}$ (II) in anaerobic bacteria: Proceedings of the National Academy of Sciences, v. 108 , no. 21 , p. $8714-8719$.

Scheuhammer, A.M., Meyer, M.W., Sandheinrich, M.B., and Murray, M.W., 2007, Effects of environmental methylmercury on the health of wild birds, mammals, and fish: Ambio, v. 36 , no. 1 , p. $12-18$.

Schreiber, Bernd, Brinkmann, Thomas, Schmalz, Viktor, and Worch, Eckhard, 2005, Adsorption of dissolved organic matter onto activated carbon-The influence of temperature, absorption wavelength, and molecular size: Water Research, v. 39, no. 15, p. 3449-3456.

Selvendiran, Pranesh, Driscoll, C.T., Bushey, J.T., and Montesdeoca, M.R., 2008, Wetland influence on mercury fate and transport in a temperate forested watershed: Environmental Pollution, v. 154, no. 1, p. 46-55.

St. Louis, V.L., Rudd, J.W.M., Kelly, C.A., Beaty, K.G., Bloom, N.S., and Flett, R.J., 1994, Importance of wetlands as sources of methylmercury to boreal forest ecosystems: Canadian Journal of Fisheries and Aquatic Sciences, v. 51, no. 5 , p. $1065-1076$.

Stookey, L.L., 1970, Ferrozine-A new spectrophotometric reagent for iron: Analytical Chemistry, v. 42, no. 7, p. 779 781.

Sunderland, E.M., Gobas, F.A.P.C., Heyes, Andrew, Branfireun, B.A., Bayer, A.K., Cranston, R.E., and Parsons, M.B., 2004, Speciation and bioavailability of mercury in well-mixed estuarine sediments: Marine Chemistry, v. 90, nos. 1-4, p. 91-105.

Tan, S.W., Meiller, J.C., and Mahaffey, K.R., 2009, The endocrine effects of mercury in humans and wildlife: Critical Reviews in Toxicology, v. 39, no. 3, p. 228-269.

Tessier, Emmanuel, Rodriguez Martin-Doimeadios, Rosa, Amouroux, Dvid, Morin, Anne, Lehnhoff, Christian, Thybaud, Eric, Vindimian, Eric, and Donard, O.F., 2007, Time course transformations and fate of mercury in aquatic model ecosystems: Water, Air, and Soil Pollution, v. 183, no. 1 , p. 265-281.

Tiffreau, Christophe, Lützenkirchen, Johannes, and Behra, Philippe, 1995, Modeling the adsorption of mercury(II) on (hydr)oxides-I. Amorphous iron oxide and $\alpha$-quartz: Journal of Colloid and Interface Science, v. 172, no. 1, p. 82-93.

Uchiyama, Taku, Ito, Kimio, Mori, Koji, Tsurumaru, Hirohito, and Harayama, Shigeaki, 2010, Iron-corroding methanogen isolated from a crude-oil storage tank: Applied and Environmental Microbiology, v. 76, no. 6, p. 1783-1788.
Ullrich, S.M., Tanton, T.W., and Abdrashitova, S.A., 2001, Mercury in the aquatic environment: A review of factors affecting methylation: Critical Reviews in Environmental Science and Technology, v. 31, no. 3, p. 241-293.

Ulrich, P.D., and Sedlak, D.L., 2010, Impact of iron amendment on net methylmercury export from tidal wetland microcosms: Environmental Science and Technology, v. 44, no. 19 , p. $7659-7665$.

U.S. Environmental Protection Agency, 1998, Method 1630 Methylmercury in water by distillation, aqueous ethylation, purge and trap, and cold vapor atomic fluorescence spectrometry: U.S. Environmental Protection Agency, EPA821-R-01-020, 41 p., plus appendix, accessed September 5, 2013, at http://water.epa.gov/scitech/methods/cwa/metals/mercury/upload/2007_07_10_methods_method_mercury_1630.pdf.

U.S. Environmental Protection Agency, 2001, Mercury update: impact on fish advisories. Fact Sheet. EPA-823-F-01-011, June 2001, 10 p., accessed February 5, 2014, at http://water.epa.gov/scitech/swguidance/fishshellfish/outreach/upload/2001_05_31_fish_advice_mercupd.pdf.

U.S. Environmental Protection Agency, 2002a, Method 1631, revision E-Mercury in water by oxidation, purge and trap, and cold vapor atomic fluorescence spectrometry: U.S. Environmental Protection Agency, EPA-821-R-02-019, 46 p., accessed September 5, 2013, at http://water.epa.gov/ scitech/methods/cwa/metals/mercury/index.cfm.

U.S. Environmental Protection Agency, 2002b, Methods for measuring the acute toxicity of effluents and receiving waters to freshwater and marine organisms: U.S. Environmental Protection Agency, EPA-821-R-02-012, 275 p.

U.S. Environmental Protection Agency, 2007, Method 7473 (SW-846): Mercury in solids and solutions by thermal decomposition, amalgamation, and atomic absorption spectrophotometry: U.S. Environmental Protection Agency, 17 p., accessed September 5, 2013, at http://www.epa.gov/ osw/hazard/testmethods/sw846/pdfs/7473.pdf.

Vernon, J.D., and Bonzongo, J-C.J., 2014, Volatilization and sorption of dissolved mercury by metallic iron of different particle sizes: implications for treatment of mercury contaminated water effluents: Journal of Hazardous Materials, v. 276 , p. $408-414$.

Wada, Haruka, Cristol, D.A., McNabb, F.M.A., and Hopkins, W.A., 2009, Suppressed adrenocortical responses and thyroid hormone levels in birds near a mercury-contaminated river: Environmental Science and Technology, v. 43, no. 15, p. 6031-6038. 
Warner, K.A., Roden, E.E., and Bonzongo, J.C., 2003, Microbial mercury transformation in anoxic freshwater sediments under iron-reducing and other electron-accepting conditions: Environmental Science and Technology, v. 37, no. 10, p. 2159-2165.

Weiner, J.G., and Spry, D.J., 1996, Toxicological significance of mercury in freshwater fish in Beyer, W.N., Heinz, G.H., and Redmon-Norwood, A.W., eds., Environmental contaminants in wildlife-Interpreting tissue concentrations: Boca Raton, Fla., Lewis Publishers, p. 297-340.

Weisener, C.G., Sale, K.S., Smyth, D.J.A., and Blowes, D.W., 2005, Field column study using zero valent iron for mercury removal from contaminated groundwater: Environmental Science and Technology, v. 39, no. 16, p. 6306-6312.

Wolfe, M.F., Schwarzbach, Steven, and Sulaiman, R.A., 1998, Effects of mercury on wildlife-A comprehensive review: Environmental Toxicology and Chemistry, v. 17, no. 2, p. 146-160.

Zhang, Yanxu, and Jaeglé, Lyatt, 2013, Decreases in mercury wet deposition over the United States during 2004-2010: Roles of domestic and global background emission reductions: Atmosphere, v. 4, no. 2, p. 113-131. 
Prepared by the Pembroke and Rolla Publishing Service Centers.

For more information concerning this report, contact:

Office Chief

Maine Office

New England Water Science Center

U.S. Geological Survey

196 Whitten Road

Augusta, ME 04330

dc_me@usgs.gov

or visit our Web site at:

http://me.water.usgs.gov 


\section{$\frac{\mathbb{3}}{\mathrm{C}}$}

